Est Ag 38 (2003) 5-61

\title{
Comentario a la Regla de san Agustín
}

\author{
CAPÍTULO CUARTO
}

PRIMERA PARTE

\section{Texto del capítulo}

1. No sea llamativo vuestro porte, ni procuréis agradar con el modo de vestir, sino con la manera de comportaros.

2. Cuando salgáis, caminad juntos; cuando lleguéis a donde os dirigís, permaneced juntos.

3. Al andar, al estar parados y en todos vuestros movimientos no hagáis nada que sirva de escándalo a la mirada de otra persona, sino lo que se ajusta a vuestra santidad.

4a. Aunque dirijáis vuestros ojos hacia alguna mujer, no los dejéis prendidos en ninguna.

4b. Pues no se os prohíbe ver mujeres cuando salís; lo que es pecado grave es desearlas o querer ser deseados por ellas. $Y$ tanto el querer que os deseen mujeres como el desearlas vosotros no lo suscita sólo el tacto y el afecto, sino también la mirada. Y no digáis que es puro vuestro interior si tenéis ojos impuros, puesto que el ojo impuro es mensajero de un corazón impuro. $Y$ cuando, aunque calle la lengua, los corazones, con la mutua mirada, se trasmiten reciprocamente mensajes impuros y, conforme a lo habitual en el deseo carnal, hallan deleite en el ardor recíproco, la castidad misma huye de las costumbres, aunque la violación impura no llegue a tocar los cuerpos.

5. Y el que deja sus ojos prendidos en una mujer y goza si ella tiene los suyos prendidos en él no debe pensar que nadie lo advierte cuando eso hace; es visto ciertamente, incluso por aquellos que menos piensa. Pero supongamos 
que su acción queda oculta y que nadie la ve, ¿qué hará de quien le observa desde lo alto y a quien nada puede quedar oculto? ¿O se ha de juzgar que no la está viendo porque la ve con tanta más tolerancia cuanto mayor es su sabiduría? A Él, pues, tema desagradar el varón santo: así evitará querer agradar con malicia a una mujer. Para evitar el deseo de mirar con malicia a una mujer, piense que Él todo lo ve. Pues también en este ámbito recomienda temerle el siguiente texto de la Escritura: Abominable es ante el Señor el que deja prendidos los ojos (Prov. 27,20).

6. Por lo tanto, cuando coincidáis en la Iglesia o en cualquier otro lugar donde haya también mujeres, proteged recíprocamente vuestra pureza. Pues Dios, que habita en vosotros, os protegerá a vosotros, sirviéndose de vosotros mismos, también de este modo.

7. $Y$ si advirtierais en alguno de vosotros esa mirada lasciva de que os estoy hablando, amonestadle sobre la marcha para que, dado que ya apuntó, no vaya a más, sino que se corrija de inmediato.

8. Si, al contrario, le viereis hacer de nuevo lo mismo tras la amonestación o cualquier otro día, quien pudo advertirlo delátelo ya como a sujeto herido que necesita curación. Previamente, sin embargo, haga que presencien su falta una segunda o una tercera persona, para que por boca de dos o tres pueda quedar convicto y sometido a disciplina con la adecuada severidad. Y no juzguéis que obráis con mala voluntad por dar a conocer la falta. Pues no causáis menos daño a vuestros hermanos, a los que podéis hacer que se corrijan señalándolos, si, por callar, permitís que perezcan. En efecto, si tu hermano tuviese una herida corporal que quisiera ocultar por miedo al tratamiento de la cura, ¿no sería cruel el silenciarla y misericordioso el darla a conocer? ¡Cuánto más, entonces, debes descubrirle a él para que la podredumbre no invada su corazón con daño mayor!

9. Pero si, una vez recibida la amonestación, la ignora, antes de hacer que presencien su falta otros que le han de dejar convicto en caso de negarla, se ha de dar a conocer al prepósito por si, corregido de esa forma menos pública, puede evitarse que llegue a conocimiento de los demás. Si, con todo, lo niega, entonces se han de presentar al (prepósito) que ignora lo ocurrido los otros testigos, para que, en presencia de todos, (el presunto culpable) pueda no ya ser acusado por un único testigo, sino dejado convicto por dos o tres. Una vez reconocido culpable, debe sufrir un correctivo según el criterio del prepósito o, incluso, del presbítero bajo cuya responsabilidad se halla. Si rehúsa aceptarlo, expulsadlo de vuestra comunidad, si no se marcha él espontáneamente. Pues 
tampoco esto se hace por crueldad, sino por misericordia, para evitar que con su pestífero contagio lleve a la perdición a otros muchos.

10. $Y$ este procedimiento que he referido a propósito de no dejar prendida la mirada obsérvese también con diligencia y minuciosidad, con amor a los hombres y odio a los vicios, a la hora de averiguar, impedir y dar a conocer los demás pecados y dejar convictos y castigar (a sus autores).

11. En cambio, aquel que haya llegado a tal nivel de maldad que reciba a escondidas cartas o regalillos de cualquier tipo de alguna (mujer), si lo confiesa espontáneamente, perdónesele y órese por él. Pero si es sorprendido y declarado culpable, reciba un correctivo más severo, según el juicio del presbítero o del prepósito.

\section{Plan 1}

En el comentario al presente capítulo, debido a su mayor extensión, procederemos de modo parcialmente distinto al seguido a propósito de los capítulos segundo y tercero. En un primer momento recogeremos cuanto han dicho otros autores sobre aspectos generales a saber: peculiaridad, tema, estructura y ubicación dentro de la Regla, añadiendo siempre nuestro propio punto de vista. En un segundo momento nos ocuparemos del comentario propiamente dicho. Pero, debido a la longitud del capítulo, lo dividiremos en dos partes. La primera se ocupará de los seis parágrafos iniciales y la segunda de los cinco restantes. A su vez, en cada una de estas partes procederemos según el método habitual: primero presentaremos y valoraremos cuanto han dicho otros autores en cuanto a los datos históricos y ascético-espirituales y luego ofreceremos nuestra propia interpretación.

1. Como los distintos comentarios a la Regla serán copiosamente citados, utilizaremos estas siglas: Cilleruelo: El monacato de san Agustín y su Regla, Valladolid 1947; CilleRuElo, Comentario: Comentario a la Regla de san Agustín, Valladolid 1994; SAGE: La vie religieuse selon saint Augustin, Paris 1972; ZuMkELLER: The Rule of Saint Augustin with a Commentary, Wisconsin 1961; MANRIQUE - SAlAS: Evangelio y Comunidad. Raíces bíblicas de la consagración a Dios en san Agustín, Madrid 1978; TRAPÈ: Sant'Agostino: La Regola, Roma $1986^{2}$; VAN BAVEL: Agustín de Hipona: Regla para la comunidad, Iquitos [Perú] 1986; BofF: El camino de la comunión de bienes, Bogotá 1991; AGATHA MARY: The Rule of Saint Augustin. An Essay in Understanding, Augustinian Press, Villanova 1992; MARIE-AnCILlA: La Règle de saint Augustin, Paris 1996; DE VoGÜE: Histoire littéraire du mouvement monastique dans l'antiquité, I-V, Paris, 1991- 1998. 


\section{Peculiaridad}

En 1979 publicaba L. Verheijen un artículo sobre el capítulo cuarto de la Regla cuyo título era revelador: «El muy difícil capítulo cuarto. El celibato monástico y la solicitud por los pecadores» ${ }^{2}$. En su introducción escribía: «En los medios para los que la Regla de san Agustín es algo más que un interesante documento histórico antiguo, su capítulo cuarto es sentido como particularmente difícil, incluso bien penoso... Precisamos que este capítulo cuarto ocupa casi una cuarta parte del texto ${ }^{3}$ de tal modo que la impresión desfavorable que se desprende de este largo pasaje se comunica fácilmente al conjunto del texto» 4 . Dejando para más adelante indicar la razón que sustenta tal juicio, baste por ahora haberlo traído a colación. Otros autores posteriores han hecho idéntica constatación ${ }^{5} \mathrm{o}$ han repetido en lo fundamental el mismo juicio ${ }^{6}$. Leyendo algunos comentarios se obtiene la impresión de que, mientras el conjunto de la Regla parece poder gozar de «curso legal», aun admitiendo que algunas normas concretas están superadas por el simple paso del tiempo, el presente sólo merece estar en circulación si ha sido sometido a una operación de rescate ${ }^{7}$. Dicho con otras palabras: respecto de los demás capítulos se acepta en general su «filosofía», aunque se juzguen desfasados algunos puntos de su casuística; mientras que, respecto a este, se cuestiona su misma «filosofía» de fondo y, en consecuencia, buena parte de la casuística. La

2. Le très difficile quatrième chapitre. Le célibat monastique et la sollicitude pour les pécheurs», en Augustiniana 29 (1979) 43-86 NA I,107-150. En adelante, Le célibat.

3. En la edición de L. Verheijen, el capítulo cuarto ocupa 60 líneas, sobre un total de 246 , seguido, en cuanto a extensión, por el quinto con 53 .

4. Le célibat, 107.

5. Esto es, sobre su desproporcionada extensión. Cf. ZuMKELLER, 83 (aunque se refiere a la parte dedicada a la corrección fraterna); AGATHA MARY, 145, que lo aduce como simple dato. En otro lugar la autora piensa que tal extensión se debe a que se trataba de una cuestión candente entre los hermanos (Looking at the Rule of saint Augustine, en Augustinian Heritage 38 [1.992] 23-36: 30). Para C. Boff el dato en ningún modo resulta neutro; el autor se pregunta, en efecto, si este capítulo de la Regla no es en gran parte responsable del desafecto que ha sufrido en los últimos tiempos (BOFF, 103). L. Cilleruelo habla de la extrañeza que produce a algunos este capítulo tan detallado y largo en un documento tan genérico y corto (Cilleruelo, Comentario, 341). Cf. también Marie-Ancilla, 215.

6. A propósito de él se habla de «Capítulo problemático» (BOFF, 103); de «impresión penosa» (CIlleruelo, Comentario, 347); de «long and often troubling chapter» (AGATHA MARY, 205).

7. «Nuestra hermenéutica se parece, en verdad, a una especie de "operación rescate". Es el modo como buscamos "salvar" el texto» (BOFF, 107). Antes se ha preguntado el autor: «después de todo lo que hemos visto sobre el espinoso capítulo IV, ¿no será mejor archivar este capítulo y pasar adelante?» (IB. 106). 
pregunta ahora es: ¿justifica realmente el contenido del capítulo juicio tan negativo? La respuesta llegará después; antes es preciso haberlo interpretado.

\section{Argumento}

También a propósito del capítulo cuarto tenemos que contar con diversidad de pareceres. Nada extraño, considerando que en cualquier ámbito el acuerdo unánime es afortunadamente más bien raro entre los estudiosos. Afortunadamente porque el desacuerdo se convierte en estímulo a la investigación y en origen de progreso en el conocimiento.

Para empezar, digamos que ediciones antiguas dividían el texto en dos capítulos. Al primero de ellos, que comprendía los seis primeros parágrafos, se le solía asignar como tema «el hábito y el porte exterior» y al segundo, que abarcaba los cinco restantes, «la corrección fraterna». Las ediciones actuales siguen el criterio unificador de la edición crítica de L. Verheijen, en la que ambas partes constituyen un único capítulo.

En cuanto al tema del mismo, hay comentaristas que mantienen una idéntica unidad. Entre ellos se cuenta L. Verheijen. Según el sabio agustino, el tema general específico del capítulo cuarto de la Regla lo constituyen las salidas de los siervos de Dios fuera del monasterio ${ }^{8}$. Por supuesto, se trata de las salidas de personas que viven en el espíritu de un propositum continentiae, aunque el legislador no haya juzgado necesario decirlo expresamente, por ser evidente ${ }^{9}$. El tema de la castidad es sólo derivado. Al juzgar que el capítulo

8. Le célibat, 45 NA I,109: «Précisons que ce n'est pas le quatrième chapitre dans sa totalité qui traite du célibat. Son sujet général est plutôt: A propos des sorties». Cf. asimismo M. Schrama, Praeposito tamquam patri oboediatur. Augustinus über Frieden und Gehorsam, en Augustiniana 41 (1991) 847-878: 862: «Und in vierten Kapitel versucht der Regelvater, das Verhältnis der Gemeinschaft zur Ausenwelt zu regeln. Es betriefft hier Menschen, die sich zufällig treffen». También Agatha Mary pone énfasis en el hecho de que en el capítulo cuarto entran en escena personas de fuera del monasterio. «But unity can never be a closed circuit system; it must always move outward. So inevitably, the Rule goes on inmediately to consider the monk outside the monastery» (AGATHA MARY, 142; cf. también, p. 148). Pero la autora no concluye que sea el tema del capítulo (cf. más adelante), sino sólo uno de sus rasgos peculiares. Otros hay que verlos en el hecho de que en él las relaciones entre las personas, lejos de ser moralmente neutras, se convierten en fuente de problemas morales; además, si hasta ahora la Regla se ha ocupado de la situación del individuo en relación con el grupo, en el presente capítulo es el grupo el que se ha de sentir responsable del individuo ( $I b .145$; cf. también Looking, 31).

9. $I b$. En sus varios artículos suele resumir el contenido del capítulo en los siguientes elementos: las salidas, las relaciones con el otro sexo, la corrección fraterna (L'enarratio in psalmum 132, 806 NA I,45; Vers la beauté spirituelle, 469; NA I,201). La misma terna con 
bien podía llevar como título «Sobre nuestra responsabilidad común frente al mal», T. van Bavel está indicando cuál es, en su opinión, el tema del mismo, tratado sobre el trasfondo del voto de virginidad 10 .

Aun considerándolo como un único capítulo, A. Sage, C. Boff, Agatha Mary y A. de Vogüé, en sus comentarios respectivos, entienden que incluye dos temas. Para el primero son «la modestia religiosa» $\mathrm{y}$ «la corrección fraterna» 11; para el segundo, «la disciplina del mirar» y «la corrección fraterna» 12; para la tercera, «el ascetismo a través de la castidad y la preocupación de unos por los otros» 13; para el cuarto, «los riesgos de las salidas y la reprensión de las faltas» 14 . Los dos últimos autores distinguen los temas, pero no los separan, ni material ni formalmente.

De dos temas hablan también otros comentaristas ${ }^{15}$. Lo que les diferencia de los anteriores es que no sólo los distinguen, sino que también los separan. Esta separación no sólo acontece a nivel físico, al tratar los temas en diversos capítulos, sino también a un nivel más formal, al considerar la corrección como un tema independiente ${ }^{16}$.

Por evidente, todos toman nota de que el tema de la castidad domina, al menos, la primera mitad del capítulo. Pero, como el término encierra cierta ambigüedad, procede advertir que no todos leen lo mismo en el capítulo de la Regla. Unos autores lo entienden en el sentido de castidad consagrada o voto de virginidad, aun reconociendo que falta la terminología específica ${ }^{17}$; otros

otra formulación: el comportamiento fuera del monasterio, las tentaciones en el dominio del celibato consagrado y la solicitud por los eventuales trasgresores (Le de sancta virginitate, 268 NA II, 180).

10. VAN BAVEL, 58.

11. SAGE, 224.231.

12. BofF, 101 y 123 , como dos secciones, A y B, del mismo capítulo.

13. AgATHA MARY, 146, en un único capítulo.

14. DE VOGǗ, 3,189.

15. ZUMKELLER, 75 ( «La vida de castidad consagrada») y 83 («La corrección fraterna en el monasterio»); TRAPÈ, 145 («Castidad») y 122 («Corrección fraterna»); A. MANRIQUE - A. SALAS, 157 ( «La guarda de la pureza del corazón») y 169 («La corrección entre hermanos»); Cilleruelo, 303 y Cilleruelo, Comentario, 339 («(De) la compostura del hombre exterior») y 343 y 370 («(De) la corrección fraterna»). A ellos podría añadirse M. Neusch (La structure de la Règle, en Itineraires Augustiniennes 4 [1990] 13-19: 15), quien establece una relación entre los dos puntos en que insiste el capítulo: las mujeres y la corrección fraterna, y los dos capítulos siguientes, el quinto y el sexto. En el caso de A. Zumkeller, A. Sage, L. Cilleruelo en Monacato se entiende porque trabajaban con una edición de la Regla en que el actual capítulo cuarto estaba dividido en dos.

16. Aunque el santo se limite a las miradas lascivas, se entiende como un ejemplo concreto de un modo de actuar más general.

17. Sobre ello, más adelante. 
rebajan considerablemente el nivel y, a su parecer, el capítulo trata específicamente de la falta de castidad ${ }^{18}$, o de las miradas impuras ${ }^{19}$, o de las infracciones a la virginidad ${ }^{20}$, o de la prevención de cualquier infracción contra la castidad ${ }^{21}$, o de todo el ambiente de pureza ${ }^{22}$, etc.

¿Qué decir de estos diversos planteamientos? Nosotros tenemos claro que no hay que considerar la castidad y la corrección como dos temas independientes. Tal planteamiento creemos que no responde a la realidad de la Regla. A nuestro parecer, el tema de este capítulo cuarto es único, como es único el de todos los restantes capítulos de la sección B. Pero eso no implica que estemos de acuerdo ni con L. Verheijen ni con T. van Bavel en la identificación de ese único tema. Que en el presente capítulo san Agustín tiene en mente la conducta de los siervos de Dios en sus salidas fuera del monasterio resulta evidente. Todo cuanto prescribe se entiende perfectamente desde esa perspectiva. Pero en las salidas al exterior hay que ver la circunstancia no la categoría. Si el legislador quiere regular el comportamiento de los siervos de Dios con las mujeres, es natural que se ubique en las circunstancias en que se pueden topar con ellas. Lo que le interesa, sin embargo, es dicho comportamiento, no el lugar, aunque no pueda prescindir de este si quiere regular aquel, dado que la Regla no se ocupa directamente de principios abstractos sino más bien de situaciones concretas. Los principios quedan en el trasfondo. Si la Regla siguiese el criterio espacial, esto es, el dentro/fuera del monasterio, resultaría extraña la ubicación del capítulo. Lo lógico sería tratar primero un aspecto en su totalidad y luego el otro. En ese caso, el tema del presente capítulo debería ocupar bien el primer capítulo ${ }^{23} \mathrm{o}$ bien el último. Ponerlo en el cuarto no tendría fácil justificación estructural.

A su vez, la propuesta de T. van Bavel nos parece que no abarca todo el contenido del capítulo. Por supuesto, el capítulo se ocupa de la responsabilidad común frente al mal; pero no todo lo que prescribe encaja en ese molde. Responde sin duda a la segunda parte del capítulo (parágrafos 6-11), pero no a la primera, a excepción quizá del segundo parágrafo. En el resto aparecen presupuestas otras personas, pero no son moradores del monasterio y, ade-

18. AGATHA MARY, Looking, 30. El término usado por la autora es «unchastity». 19. MARIE-ANCILLA, 215. BAVEL, 58).

20. «En la Regla se trata exclusivamente de las infracciones a la virginidad» (VAN

21. A. SAGE, La vie religieuse, 223.

22. F. MORIONES, Espiritualidad agustino-recoleta, II, 157: «Comienza con la misma modestia en el vestir hasta la más profunda consagración a Dios por la virginidad».

23. En este caso, el segundo, dejando de lado el primero que ofrece los principios fundamentales. 
más, no tienen responsabilidad alguna respecto a los siervos de Dios, salvo la responsabilidad moral común a toda persona.

Queda por considerar el grupo de autores que juzgan que el capítulo contiene dos temas, aunque interrelacionados entre sí. Es este último particular lo que separa a sus representantes del planteamiento descartado con anterioridad. En primer lugar, no nos parece acertada la propuesta de Agatha Mary que percibe un doble tema: castidad e interés mutuo. Se le puede objetar que la preocupación mutua («mutual concern») de que habla aparece también en otros capítulos (quinto, sexto y séptimo) y, por tanto, no cabe ponerlo como tema propio del capítulo cuarto. Equivaldría a admitir en la Regla repeticiones formales, esto es, tratar el mismo tema en varios capítulos ${ }^{24}$. Respecto a quienes proponen la castidad junto con la corrección fraterna, el acuerdo o desacuerdo depende del modo de entender la relación entre ambos temas. Nuestra comprensión es la siguiente: Dando por hecho que en su materialidad el capítulo trata de la castidad y de la «corrección fraterna» 25 , juzgamos que el tema del capítulo es, en la mente del legislador, único: el de la castidad. Si se ocupa de la «corrección fraterna» no es porque el santo quiera introducir ese tema específico, sino sencillamente porque se lo reclama el tema de la castidad. No cabe pensar que san Agustín quiera considerar primero el tema de la castidad y luego el de la «corrección fraterna», tomando del primer ámbito el ejemplo para indicar cómo se ha de proceder en el segundo. Al contrario, de no haber introducido el tema de la castidad con sus características propias, no hubiese aparecido el tema de la «corrección fraterna». Ha de considerarse, pues, el tema de la castidad como el único del capítulo. Él cubre todos y cada uno de sus parágrafos, incluidos los tres primeros 26 .

24. Las repeticiones materiales, esto es, tratar los mismos temas en diversos capítulos: p. ej., los vestidos en praec. 3,4; 4,1;5,1.4.11 no ofrecen problemas, porque se pueden considerar desde distintos puntos de vista, como así es en realidad.

25. Dejamos de lado por ahora el hecho de que no nos parece adecuado hablar de «corrección fraterna» para recoger el contenido de la segunda parte del capítulo. A eso se debe el entrecomillado. La razón aparecerá cuando nos ocupemos de comentar el texto.

26. L. Verheijen no ve ninguna alusión directa al celibato en las primeras líneas del capítulo: «Aucune allusion directe donc au célibat dans ces premières lignes. Mais tout le reste du chapitre y est consacré, de la première ligne qui dit: Votre regard... jusqu'à la dernière...» ( $L e$ célibat, 45 NA I,109). Agustín comenzaría a hablar del celibato, pues, sólo a partir de praec. 4,4.A. Trapè, por su parte, pasa por alto los parágrafos 1-2 del capítulo cuarto al ocuparse del tema de la castidad en la Regla (cf. La regola, 145ss). Pero aunque no haya alusión directa, creemos que su interpretación correcta se coloca en ese ámbito, como ve verá más adelante. 
Sólo por comodidad nos hemos servido del término «castidad» para indicar el único tema de este capítulo cuarto. Es el momento de precisar un poco más. Ya vimos cómo los autores se muestran indecisos a la hora de señalar la perspectiva concreta desde la que es considerado ese tema. Para poder afirmar que el tema del capítulo es la castidad consagrada, voto de virginidad o celibato, es preciso establecer antes una división. Hay que distinguir entre el aspecto ascético y el aspecto místico. El aspecto ascético viene a identificarse con la virtud de la castidad. Esta virtud tiene unas exigencias que no son iguales para un soltero, un casado o un célibe o una persona que ha consagrado a Dios su virginidad. El aspecto místico se refiere sobre todo a la motivación y al sentido de esa opción. Es obvio que puede haber ascesis de la castidad sin mística, pero lo es también que no cabe mística de la castidad sin la respectiva ascesis previa. Este capítulo cuarto se centra, pues, en el aspecto ascético de la castidad. Y, a más abundamiento, ha de tenerse en cuenta que lo que propone en la primera parte es válido para todo cristiano, no sólo para los que se han consagrado a Dios en castidad perfecta 27.

Un caso similar lo podemos encontrar en un texto que con toda seguridad leyó san Agustín: la célebre carta de san Jerónimo a la virgen Eustoquia. El monje betlemita acaba de hacer mención de los distintos tratados sobre la virginidad que ofrecía entonces la literatura cristiana latina, concluyendo con el de san Ambrosio, del que afirma: «En ellos se explaya tan elocuentemente, que todo lo que se puede decir para elogio de la virginidad está allí estudiado, descrito». Y a continuación añade: «Nosotros seguimos otro enfoque; no exaltamos la virginidad, sino que la guardamos» ${ }^{28}$. Más que de hacer panegíricos, se ocupa de indicar a la joven los peligros que la acechan y cómo podrá superarlos. Algo parecido tenemos en el capítulo cuarto de la Regla. El que el legislador no entre en lo que hemos llamado el aspecto místico no implica que lo desconozca, ni siquiera que esté del todo ausente de la Regla, como se verá en su momento, sino que aquí lo pasa por alto. En cualquier caso, siempre queda por explicar tal silencio en el momento en que era de esperar una palabra al respecto. La respuesta nos llegará de los apartados siguientes, que nos darán la oportunidad de matizar aun más el tema del capítulo.

27. A lo más, se podría exceptuar lo que ordena en el parágrafo segundo. Con todo, aunque no siempre fuera viable para otras personas no residentes en el monasterio, propone un modo de actuar válido para todos los que deseen guardar la virtud de la castidad.

28. «In quibus tanto se fudit eloquio, ut quidquid ad laudem uirginum pertinet exquisierit, ordinarit, expresserit. Nobis diuerso tramite inceditur: uirginitatem non efferimus, sed seruamus» (ep. 22,22-23; traducción de J. B. Valero en SAN JERÓNIMO, Epistolario, edición bilingüe, Madrid BAC 530, p. 230-231). 


\section{El porqué de su ubicación en la Regla}

La sucesión de los capítulos de una obra no es fruto del azar. Responde a un criterio del autor, no siempre explicado, como en el caso presente. Por ello no nos queda sino hacer conjeturas. Es una cuestión que pocos autores se plantean. Lo normal es que se contenten con una afirmación genérica referida al conjunto de capítulos de la sección $\mathrm{B}$, sin entrar en detalles sobre el orden entre ellos ${ }^{29}$. Quien, sin embargo, sí la ha planteado es A. de Vogüé. Según este erudito benedictino, la preocupación de san Agustín por las personas, rasgo específico de su Regla, se despliega en dos series de consideraciones. La primera tiene por objeto las cosas necesarias para la vida -alimento y vestido- ${ }^{30}$, y la segunda, las tres virtudes esenciales del religioso: castidad, pobreza y obediencia ${ }^{31}$. A juicio del autor, pues, el texto de $1 \mathrm{Tim} 6,8$ es el que orienta la sucesión de los temas en los capítulos tercero y cuarto ${ }^{32}$. El texto paulino le lleva a hablar del vestido y, con ocasión de este, trata respectivamente de la castidad (cap. cuarto) y de la pobreza (cap. quinto) ${ }^{33}$. A nuestro parecer, sin embargo, el camino seguido por el legislador es el contrario: por-

29. Así, por ejemplo, L. Verheijen: «Les chapitres suivants, I à VII, élaborent dans le détail les diverses aspects de la vie monastique communitaire dont l'auteur a établi l'inspiration générale dans son premièr chapitre: aspects communautaires de la prière; la table commune; les sorties et la sauvegarde mutuelle des engagements dans le cadre du célibat consacré...» (Eléments d'un commentaire de la Règle de saint Augustin. XV. Comme amants de la beauté spirituelle. Dans Augustin évêque, en Augustiniana 32 [1982] 88-136: 92 NA II, 121; Le De sancta Virginitate de saint Augustin et sa estructure. Un complément à l'étude du chapitre quatrième, en Augustiniana 32 [1982] 266-281: 267-268 NA II, 179-180).

30. Detrás está la referencia a 1 Tim 6,8: «Teniendo alimento y vestido, hemos de contentarnos con ello».

31. DE VoGÜÉ, 3,177. Estas dos secuencias se recubren en parte: después de haber considerado principalmente el alimento (cap. 1 y 3), Agustín se ocupa del vestido (4-5) y, a propósito de este, trata a su vez el tema de la castidad y la pobreza. Un poco más adelante observa que, si el conjunto alimento-vestido está claramente indicado, la tríada de las virtudes, de las que sólo la primera es indicada por su nombre (4,4: castitas), puede parecer un poco artificial, inspirada en categorías modernas (cf. $i b$.$) .$

32. «"Vivres et vêtements": ces deux besoins fondamentaux figuraient déjà côte a côte dans les propos sur la distribution inégale du nécessaire. Tel est donc le fil qu'Augustin parait suivre en rédigeant sa règle» (DE VoGÜÉ, 3,173).

33. «La nourriture le conduit au vêtement. Mais celui-ci será considéré sous deux rapports différents: son aspect, par lequel il parle au regard des gens du dehors, et son appartenance, qui en fait la chose de l'individu ou de la communauté. La première de ces considérations introduit le thème des sorties, qui va lui-même amener deux questions importantes: les fautes contre la chastité et leur répression» (DE VOGÜÉ, 3,173; cf. también p. 189). 
que ha determinado hablar de la castidad, habla también del vestido ${ }^{34}$. Más que arrastrar a otros, el tema del vestido es arrastrado por otro ${ }^{35}$.

Poco acertado nos parece asimismo el planteamiento de A. Salas y A. Manrique quienes advierten una progresión en la vía de la espiritualización: si el ayuno de que habla el capítulo tercero orienta al siervo de Dios hacia los bienes de orden espiritual, la práctica de la virginidad le introduce, ya en esta tierra, en un ambiente en cierto modo angélico y celestial ${ }^{36}$. De una parte, no se puede reducir el capítulo tercero al tema del ayuno; de otra, el capítulo cuarto nos parece bastante alejado del mencionado angelismo celestial. Por último M. Neusch, al contrario de los precedentes autores, desvincula el capítulo cuarto del tercero y lo contrapone a los dos siguientes: mientras aquel se ocupa de la vida fuera del monasterio, estos dos lo hacen de la vida dentro de él ${ }^{37}$. Pero la estructura que propone no nos parece sostenible ${ }^{38}$.

Es precisamente la estructura que hemos propuesto la que explica con claridad la razón por la que al tema del alimento (cap. tercero) sigue el de la castidad (cap. cuarto). Es el momento de recordar, primero, que los capítulos tercero y cuarto forman la «unidad» segunda de la sección B de la Regla y, luego, que dicha «unidad» incluye en todos los textos de estructura y contenido paralelos a la Regla el tema del alimento y el de la sexualidad. En consecuencia, habiéndose ocupado el santo en el capítulo tercero de regular, fundamental aunque no exclusivamente, lo que se refiere al ámbito alimentario, en el cuarto tiene que regular lo referente al ámbito sexual.

A partir de aquí ya podemos clarificar mejor el tema específico del capítulo cuarto. Es oportuno traer a la memoria que nosotros interpretamos el capítulo tercero en clave de salud. Pero en la existencia humana la salud está

34. Si el criterio orientador hubiese sido el propuesto por A. de Vogüé, no se entendería que ya en el capítulo tercero hubiere introducido el tema de los vestidos y que volviese sobre él en el quinto (cf. praec. 3,4,1.59; 5,1 1. 139-152.163).

35. En ese planteamiento le había precedido Agatha Mary quien también explica con 1 Tim 6,8 el sucederse de los temas de los capítulos tercero y cuarto: «Mention of food leads naturally to the matter of clothing» (AGATHA MARY, 145).

36. A. MAnRIQue - A. SAlas, 157. La idea la recoge luego F. Moriones (Espiritualidad agustino-recoleta, II, 256.

37. «Les autres chapitres abordent certains aspects concrets, successivement la vie hors du monastère (4), avec insistance sur deux points: les femmes et la correction fraternelle; et la vie à l'intérieur du monastère, sous le double aspect matériel: les services (5), et spirituel: le pardón (6)» (Structure, 15).

38. De una parte, para mantenerla se ve obligado a separar el tema de las mujeres y de la corrección en el cap. cuarto; de otra, no se ve por qué el capítulo séptimo no ha de referirlo a la vida dentro del monasterio, por no hablar también de los restantes. 
siempre relacionada con la enfermedad, de la que es superación. En el caso dèl capítulo tercero se trata de la enfermedad «natural» del hombre, cuyos síntomas principales son el sentir hambre, sed, frío y cansancio. Formando el capítulo cuarto una «unidad» estructural con el tercero, resulta lógico interpretarlo desde la misma clave: de salud o, si se quiere, de enfermedad. La enfermedad que el legislador tiene en mente es la misma del capítulo anterior, la «natural», fruto del pecado de Adán; lo que varía es el síntoma: la rebelión de la carne contra el espíritu, pero en el ámbito específico de la sexualidad. Se puede, pues, interpretar este capítulo cuarto en clave de salud, pero manifestada no ya como dominio del hambre, sed, frío y cansancio, sino como dominio de la carne, que se rebela contra el espíritu en el ámbito sexual ${ }^{39}$. Sólo que a esto lo llamamos virtud de la castidad, sin que sea necesario mantener el término más genérico de salud. La castidad, tema del capítulo cuarto, hay que contemplarla aquí en su significado de superación de una enfermedad que sufre todo hombre.

Lo dicho explica la relación entre el capítulo tercero y el cuarto. Otra cuestión es su ubicación en el conjunto de la Regla. La respuesta ya la dimos al comentar el capítulo tercero. Por ello, nos limitamos a repetir lo ya dicho. Los capítulos tercero y cuarto forman la «unidad» segunda porque su contenido responde a la segunda relación fundamental del hombre. Si la primera «unidad», o capítulo segundo, se ocupaba de la primera de esas relaciones, la que el siervo de Dios mantiene con Dios (hecha efectiva a través de la oración), esta segunda «unidad» se ocupa de la relación del siervo de Dios consigo mismo. Además de amar a Dios ha de amarse a sí mismo. En el trasfondo se puede adivinar el mismo orden establecido por el mandamiento del amor con su triple objeto: en primer lugar, Dios; luego, uno mismo; por último, el amor al prójimo (cf. Mt 22,37-40). Este amor a sí mismo se manifiesta aquí en mantener la salud tanto del cuerpo como del alma ${ }^{40}$. Si el capítulo tercero defiende los derechos del cuerpo frente a eventuales pretensiones excesivas del alma, el cuarto aboga por la libertad del alma, frente a reclamaciones indebidas del cuerpo.

39. Estas dos manifestaciones de la enfermedad están relacionadas, respectivamente, con la salud a nivel individual y con la salud a nivel de especie. Cf. Comentario al capitulo tercero en Estudio Agustiniano 37(2002) p. 283, n. 28 «The whole of this chapter is about healing, and healers must have a light touch» (AGATHA MARY, 169).

40. Cf. Comentario al capítulo tercero en Estudio Agustiniano 37 (2002) p. 284. 


\section{Estructura del capítulo}

El docto agustino T. van Bavel presenta la siguiente estructura:

1. Orientaciones generales sobre la conducta intachable,

2. especificadas hacia la actitud interior con respecto al otro sexo.

3. Responsabilidad común por las faltas de cada uno.

4. Procedimiento de la reprensión.

6. Este modo de proceder vale también como modelo para las demás fal$\operatorname{tas} 41$.

Los demás autores, aunque no expliciten estructura alguna, la reflejan en su comentario. Por supuesto, predomina la división básica en dos partes, como apareció ya al hablar del tema del capítulo. No obstante, existen diferencias entre los distintos comentaristas.

Agatha Mary, por ejemplo, recurre a un doble criterio de división. Siguiendo una propuesta de G. R. Dunstan, divide el capítulo en dos partes. La primera corresponde a los tres parágrafos iniciales, cuyo contenido valora como «principios de primer orden»; la segunda, a los ocho restantes, designando su contenido simplemente como «reglas» 42 . Por otra parte, el epígrafe que antepone al comentario del capítulo: «el ascetismo a través de la castidad y la preocupación de los unos por los otros», presupone una nueva división, siempre en dos partes. A la primera parte se refieren los parágrafos 1-5 y a la segunda los parágrafos 6-11 43. Pero no es este tampoco el último criterio de división, pues considera como una unidad a se los parágrafos 4-9, centrados en casos concretos, mientras que asigna al parágrafo siguiente un alcance general ${ }^{44}$.

Según A. de Vogüé estas son las partes que estructuran el capítulo: 1. consideración del vestido, como aspecto externo de la persona (par. 1); 2 . en relación con ello, salidas del monasterio y relaciones con las mujeres encontradas fuera (par. 2-4a); 3. faltas cometidas en este dominio (par. 4b-6); 4. generalización del procedimiento penal (par. 7-10), y 5. castigo de un delito particular: correspondencia clandestina con una mujer 45 .

Para L. Verheijen el capítulo contiene dos partes fundamentales: la primera, sin que el santo lo afirme expresamente, por juzgarlo innecesario, trata

41. VAN BAVEL, 59.

42. Agatha Mary, 149-150.

43. $I$ b. 145.

44. $i b ., 189$ : «the very heart of his understanding of monastic life».

45. DE VoGÜÉ, 3, 189. Las indicaciones numéricas son nuestras. 
del celibato consagrado y corresponde a los seis primeros parágrafos 46 ; la segunda, de la corrección fraterna, primero a propósito de las relaciones con las mujeres y luego a propósito de cualquier pecado 47 . G. Lawless distingue entre los tres primeros parágrafos que regulan la conducta fuera de los muros del monasterio, y otras tres secciones, no especificadas, que tratan del celibato monástico 48 .

También del comentario de Marie-Ancilla se puede deducir su comprensión de la estructura del capítulo que podemos presentar de esta manera: 1. Vestido y porte (par. 1.3). 2. Las miradas impuras: a) pecado contra la castidad (par. 4-5a); b) frenadas por el temor (par. 5b). 3. La corrección fraterna: a) a propósito de las miradas (par. 7-9); b) lucha contra cualquier pecado (par. 10). 4. Cartas o regalos recibidos a escondidas (par. 11) ${ }^{49}$.

En vez de hacer observaciones a cada una de las estructuras presentadas, aludidas o simplemente presupuestas por los distintos autores reseñados, preferimos presentar la que, a nuestro juicio, subyace a los preceptos del capítulo. Ella encierra en sí misma el juicio sobre las demás.

Los presupuestos base son: a) el tema del capítulo, en su primera parte, es la dimensión ascética del celibato o virginidad, la virtud de la castidad en el nivel exigido a cualquier fiel. b) Dicha virtud es expresión de salud, en cuanto superación de una específica enfermedad «natural», cuya sintomatología es la rebelión de la carne contra el espíritu en el ámbito de la sexualidad. Los dos conceptos, salud y enfermedad, son correlativos y ambos se pueden utilizar como criterio para fijar la estructura del capítulo. No obstante, preferimos el segundo, el de enfermedad, que aparece explícitamente mencionado en el texto. En el parágrafo octavo, el siervo de Dios aparece como un enfermo (uulneratum) y, para justificar el tratamiento de su enfermedad, enfermedad espiritual en este caso, el santo recurre al paralelismo con la enfermedad física ${ }^{50}$. Y en el parágrafo noveno vuelve a utilizar la terminología médica ${ }^{51}$.

46. El autor se expresa, sin embargo, más cautamente: «Cette partie de la Règle suppose, sans le dire en toutes les lettres et comme un acquis dont on n'a même pas besoin de parler, que les "frères" vivent dans le "célibat" consacré» (Les sermons, 376 NA I,172). Bajo esa forma de expresarse está el hecho, creemos, de no considerar que el tema se halle presente en los tres primeros parágrafos del capítulo, y juzque que los parágrafos 4-6 están desvinculados en buena medida de los anteriores. Cf. L. VERHEIJEN, Le célibat, 52 NA I,116.

47. $I b$. 474: 466 .

48. The Rule of Saint Augustin as a Mirror of perfection, en Angelicum 58 (1981) 460 -

49. Cf. MARIE-ANCILla, 133-141.211-221. Las divisiones y subdivisiones numéricas y alfabéticas son nuestras.

50. «... iam uelut uulneratum sanandum prodat... uulnus haberet in corpore.... pernitiosius putrescat...» (praec. 4,8,1.110-111. 116.118-119).

51. «ne contagione pestifera plurimos perdat» (praec. 4,9,1.129). 
Nos parece evidente que el capítulo consta de dos partes netamente definidas, que corresponden respectivamente a los parágrafos 1-6 y 7-11. Teniendo como punto de referencia la enfermedad, a la primera se la puede considerar como terapia preventiva y a la segunda como terapia curativa 52 . Es decir, en la primera parte el legislador contempla la posibilidad de que el siervo de Dios pueda caer en la enfermedad y prescribe los remedios para evitarlo; en la segunda contempla la posibilidad de que la enfermedad se haya manifestado ya y prescribe el modo de vencerla, es decir, cómo puede recuperarse la salud en ese ámbito específico.

Detengámonos en la primera parte. El siervo de Dios puede caer en la enfermedad, esto es, perder la virtud de la castidad, o bien porque él busca seducir a una mujer o bien porque resulta seducido por ella. Ambas posibilidades están contempladas en el capítulo. El contenido del primer parágrafo se explica teniendo en cuenta que, de forma consciente o inconsciente, el siervo de Dios puede buscar en el vestido una forma de seducción. Así habría que entender el agradar, leído a la luz del parágrafo quinto que habla expresamente de «agradar con malicia» (male placere) a las mujeres. Esto no es otra cosa que la seducción de carácter erótico, aunque no se piense en llegar a sus últimas consecuencias.

Dígase lo mismo del segundo parágrafo que recomienda salir juntos y permanecer juntos hasta llegar al destino. El precepto se entiende también perfectamente como defensa contra la seducción, tanto activa como pasiva 53 .

El tercero no nos deja la menor duda al respecto. Pero sólo se percibe con claridad desde una traducción más explícita que la habitual. El problema radica en cómo entender el offendere aspectum. Se le puede dar una traducción genérica: ofender la mirada de otra persona, o una más específica, que creemos es la que responde a la verdad: servir de tropiezo (moral) para la mirada de otra persona. Este servir de tropiezo no indica otra cosa que ser ocasión de pecado. ¿Cómo? Intentando seducirla.

El parágrafo cuarto es continuación del tercero, pero en la dirección opuesta. La continuación se manifiesta en que continúa con el tema de las miradas; la dirección opuesta, en que ahora el siervo de Dios ya no es contemplado como eventual seductor sino como posible seducido. La recomendación inicial de no dejar prendidos los ojos en una mujer implica no quedar seducido por ella (par. 4a). 278,2 .

52. A esta distinción recurre san Agustín en más de una ocasión. Cf. en. Ps. 7,10; s.

53. Cf. más adelante, al hablar de los aportes históricos. 
Esta doble dirección se manifiesta claramente en la continuación del texto, el parágrafo $4 \mathrm{~b}$. En el primero de ellos hace referencia tanto a desear a las mujeres como a querer ser deseados por ellas. Ahora bien, quien desea a una mujer, trata de seducirla; quien apetece ser deseado por ella, la quiere seductora. Esta doble actitud, activa y pasiva, vuelve a aparecer de inmediato al indicar cómo surge en el siervo de Dios, igual que en cualquier otro varón, tanto el querer que le deseen las mujeres como el desearlas él a ellas, es decir, tanto el quererlas seductoras como seducidas.

Hasta aquí lo que hay que evitar. A continuación señala por qué hay que evitarlo (4,4b) y el cómo (4,5-6). Y en el cómo implica en primer lugar al propio siervo de Dios $(4,5)$ y en el segundo lugar a la comunidad en su conjunto $(4,6)$.

A pesar de todas las recomendaciones, la terapia preventiva puede no haber resultado eficaz. Por ello el legislador da curso a una terapia curativa. Tal es el contenido de la segunda parte del capítulo (4,7-11), en la que se contempla la enfermedad en dos etapas: incipiente (4,7-10) ${ }^{54}$ y avanzada $(4,13) 55$. La primera etapa, a su vez, consta de dos momentos: uno, centrado en un síntoma específico de la enfermedad ${ }^{56}$, indicando la terapia curativa adecuada (4,7-9); otro, que extiende a los demás síntomas de la misma enfermedad el procedimiento propuesto $(4,10) 57$.

Presentada en esquema, he aquí la estructura del capítulo cuarto que proponemos:

I. Terapia preventiva (par. 1-6)

1. Qué debe evitarse (par. 1-4a)

a) Utilizar el modo de vestir como recurso seductor (par. 1)

b) Utilizar las salidas del monasterio como ocasión de seducción (par. 2).

c) Utilizar la mirada al servicio de la seducción:

1) Desear seducir a una mujer (par. 3).

2) Dejarse seducir por una mujer (par. 4a).

2. Por qué debe evitarse (par. 4b).

3. Recursos para evitarlo (par. 5-6).

54. «... ne coepta progrediatur...» (praec. 4,7,1.107).

55. «... in tantum progressus fuerit malum...» (Praec. 4,11,1.134). El contenido de este último parágrafo permite concluir que no andan acertados quienes juzgan que la segunda parte del capítulo trata, sin más, de la «corrección fraterna».

56. «... hanc de qua loquor oculi petulantiam...» (praec. 4,7, 1. 106); «... quod dixi de oculo non figendo...» (ib. 4,10,1.130).

57. «... etiam in ceteris... peccatis...» (praec. 4,10,1. 130-131). 
a) Implicación del propio siervo de Dios (par. 5).

b) Implicación de los demás siervos de Dios (par.6).

II. Terapia curativa (par. 7-11)

1. Estadio incipiente de la enfermedad (par. 7-10)

a) actuación sobre el síntoma de la mirada (par. 7-9).

b) extensión del procedimiento a los demás síntomas (par. 10).

2. Estadio avanzado de la enfermedad (par.11).

\section{Datos desde y para la historia}

No obstante su notable extensión comparado con los demás capítulos de la Regla, el presente no es de los más ricos en información sobre la historia del monacato. A pesar de que el legislador tiene en mente la vida de los siervos de Dios fuera del monasterio, es muy parco en datos al respecto. Como tantas veces acontece en san Agustín, a él le interesa más recalcar los movimientos del corazón que los del cuerpo; las relaciones personales en sí más que las condiciones exteriores en que tienen lugar. Lo cual no quiere decir que el capítulo se quede en la pura abstracción; lo que ordena está vinculado a situaciones concretas.

Como prólogo puede servir la siguiente pregunta: ¿los preceptos responden a casos dados en la comunidad destinataria de la Regla u obedecen a un planteamiento puramente teórico? $\mathrm{El}$ texto no indica si estamos ante una realidad o una ficción. Dos autores, al menos, responden a la cuestión. Mientras uno se inclina por la primera opción ${ }^{58}$, otro combina ambas opciones, en cuanto que juzga que en el origen quizá existió un hecho concreto, del que luego el legislador tomó pie para indicar cómo actuar en el caso hipotético del pecado persistente de un hermano ${ }^{59}$.

Como ya hemos indicado, el que san Agustín trate en la Regla este tema obedece más bien a un planteamiento general de base fundamentalmente antropológica. En ella, el legislador contempla al siervo de Dios en todas sus dimensiones y aspectos, uno de los cuales es su condición de persona sexuada, vista aquí como fuente de problemas para quien tiene en el horizonte la posesión de Dios, problemas a los que se propone dar solución. Pero el tratamiento que hace es más bien práctico que teórico. $\mathrm{Si}$, de hecho, la mirada monopoliza casi toda su atención, se debe a la importancia que tiene en el origen del problema al que se enfrenta; si el legislador se centra en ella, se debe

58. Cilleruelo, Comentario, 342, quien habla de «situaciones muy concretas». 59. AGATHA MARY, 190.202. 
fundamentalmente a que se trata de un aspecto que debe cuidar toda persona que pretenda guardar no ya el voto, sino la simple virtud de la castidad. De hecho, se ocupa de problemas concretos que pueden surgir en cualquier momento en el monasterio, si es que no han surgido ya, sin que sea necesario pensar en ningún escándalo vinculado a personas con nombres y apellidos en una determinada circunstancia. Con otras palabras, si no es obligado ver detrás de las prescripciones de este capítulo una historia real, sí cabe leer en él una historia posible de cada día.

\subsection{Parágrafo primero}

Al hablar del modo de vestir, el parágrafo primero plantea al historiador la cuestión de si los siervos de Dios destinatarios de la Regla disponían de un hábito monástico específico.

A juzgar por el tono general de la Regla, hay que deducir que la advertencia no responde a un simple planteamiento teórico, sino a situaciones muy posibles. El énfasis que pone en la cuestión del vestido en la obra La virginidad consagrada 60 es un argumento más. Todo parece indicar que en el monasterio no faltaba cierto aire de mundanidad 61 .

De entrada queda descartado que el término latino habitus haya de interpretarse como hábito monástico en el sentido de la tradición posterior. El término indica el porte externo de la persona, al que contribuye en buena medida la ropa (uestes) que lleva. El uso del plural (uestes) podría interpretarse como la negación de que existiera un modo de vestir uniforme para todos, pero no es necesariamente el caso; ese modo de expresarse tendría sentido aun en la circunstancia de que existiera, siempre que no se tratase de una pieza única.

Casi unánimemente los autores niegan la existencia de un específico hábito monástico. Sostienen que el vestuario de los siervos de Dios no se distinguía del de la gente ordinaria más que por la inferior calidad del tejido y por su color más oscuro ${ }^{62}$. Pero no hay que hacer mucho hincapié en el primer aspecto por dos razones: de un lado, la Regla deja entender claramente que había vestidos de buena calidad, razón por la que a sus antiguos propietarios les costaba desprenderse de ellos ${ }^{63}$; de otro, porque, aunque san Agustín

60. S. virg. 34,34.

61. Cf. MARIE-ANCILLA, 213.

62. Cilleruelo, 302; Cilleruelo, Comentario, 339; Zumkeller, 77; Sage, 224; Boff, 107; van Bavel, 59; Agatha Mary, 147; MarIe-AnCilla, 211; De VogÜÉ, I 264; III 120 y 297.

63. Cf. praec. 5,1,1.146-148. 
rechazaba que le regalasen prendas de vestir de alto valor ${ }^{64}$, él personalmente no era cicatero, según el dato de san Posidio: «Su indumenta, calzado y ajuar doméstico eran modestos y convenientes: ni demasiado llamativos ni demasiado viles» 65 . Hecha esa salvedad, digamos que son varios los argumentos a favor de la tesis de que no existía un hábito monástico específico: datos de la Regla, datos del resto de la obra agustiniana y datos de la propia historia del monacato.

La Regla incluye algunos apuntes dignos de tomarse en cuenta. Según el capítulo tercero, los siervos de Dios procedentes de costumbres más delicadas, podían recibir un vestuario (vestimenta) diferente al de los demás ${ }^{66}$. El parágrafo inicial del capítulo quinto revela las discusiones que existían en el monasterio por motivo de la calidad de los vestidos, quejándose algunos de haber recibido algo peor de lo que antes había llevado, juzgando que no se ajustaba a su categoría el vestir como había vestido su hermano ${ }^{67}$. El texto deja entender que los siervos de Dios habían llevado al monasterio la misma ropa que habían usado en su vida secular, cada cual a tono con su categoría social, y que algunos no querían desprenderse, dentro ya del monasterio, de la misma. Además, el parágrafo tercero del mismo capítulo constata que familiares o allegados llevaban prendas de vestir a los siervos de Dios que moraban en el monasterio 68. En realidad, estos datos no son en sí decisivos ni a favor ni en contra de un hábito monástico específico. Pues los interesados, al entrar en el monasterio, bien podían haber adquirido la ropa ateniéndose, por lo que a la forma se refiere, a lo que sabían ya que eran los usos del monasterio ${ }^{69}$. Dígase lo mismo de quienes hacían los regalos.

El resto de la obra agustiniana aporta algunos datos significativos. La obra El trabajo de los monjes habla de personas hipócritas desperdigadas por doquier con apariencia de monjes ${ }^{70}$.

64. Cf. s. 356,13. Cf. el texto más adelante en nota 73.

65. «Vestes eius et calceamenta uel lectualia ex moderato et competenti habitu erant, nec nitida nimium, nec abiecta plurimum» (Vita Augustini, 22).

66. «Et si eis qui venerunt ex moribus delicatioribus... aliquid... uestimentorum... datur, quod aliis... non datur...» (praec. 3,4, 1. 59-60).

67. Praec. 5,1: «Si auten hic inter uos contentiones et murmura oriuntur, cum queritur aliquis deterius se accepisse quam prius habuerat et indignum se esse qui ita uestiatur, sicut frater eius uestiebatur...» (praec. 5,1,1.145-148).

68. Praec. 5,3: «... ut etiam si quis filiis, uel aliqua necessitudine ad se pertinentibus, in monasterio constitutis, aliquid contulerit, uel aliquam uestem...» (praec. 5,3, 1. 161-163).

69. Boff, 107 deduce de aquí que la ropa era variada. Sí, pero esa variación puede referirse sólo a la calidad de la tela de que estuviera confeccionada.

70. «... tam multos hypocritas, sub habitu monachorum usquequaque dispersit» (op. mon. 28,36). Este habitus indica sin duda la apariencia exterior que incluye por supuesto el vestido. Pero no indica cuál era. Lo que si llama la atención al respecto es el detalle que 
Un nuevo dato nos lo ofrece la ep. 262, dirigida a una cierta Ecdicia que había llegado a un acuerdo con su marido para vivir en continencia perfecta. La carta la provocó el hecho de que ella, llevada de un excesivo celo ascético, cambió, entre otras cosas, su atuendo contra la voluntad de su marido. El obispo de Hipona le hace el siguiente reproche:

Cierto que está escrito que las casadas deben llevar un vestido arreglado, y que se reprenden con razón los adornos de oro, los cabellos rizados y otras semejantes frivolidades, que suelen usarse por vana pompa o para hacer atractiva la figura. Pero, según la categoría de las personas, hay un vestido matronal, distinto del de las viudas, que puede convenir a las casadas bautizadas, manteniendo el respeto a la religión... ¿Hay cosa más absurda que el que una casada se gloríe de la humildad de su vestido ante su esposo? Lo que te convenía era agradarle con tus cándidas costumbres y no molestarle con tu oscuro vestido. Aunque te gustase mucho el atuendo monacal, podías haberlo propuesto y solicitado de tu marido, pero no ponértelo sin consultarle y despreciándole a él... ${ }^{71}$.

Aunque el texto habla de un hábito monacal (indumentum monachae) todo hace pensar que no se refiere a ningún hábito específico sino más bien a un atuendo oscuro (nigellis uestibus). De hecho, a continuación lo identifica con el atuendo de viuda ${ }^{72}$. Lo que deja entender que dicho hábito de monja se distinguía del ordinario sólo por el color.

Un tercer texto, puesto muy de relieve por los autores, lo encontramos en el sermón 356, que se coloca en línea con lo que hemos visto en la Regla. El texto es el siguiente:

Yo mismo deseo que sea del común todo lo que tengo; por eso no quiero que vuestra santidad me ofrezca a título personal cosas que sólo yo pueda llevar con cierta decencia. Se me ofrece, por ejemplo, un "birro" de valor;

añade a continuación de que aireaban sus fimbrias y filacterias («alii fimbrias et phylacteria sua magnificant»). Pero aquí se trata de monjes desvinculados de los monasterios de Agustín.

71. «Scriptum est quidem mulieres esse debere in habitu ordinato aurique circumpositio et intortio crinium et cetera huiusmodi, quae uel ad inanem pompam uel ad inlecebram formae adhiberi solent, merito reprehensa sunt (cf. 1 Tim 2,9; 1 Pe 3,3). Sed est quidam pro modulo personae habitus matronalis a uiduali ueste distinctus, qui potest fidelibus coniugatis salua religionis obseruantia conuenire... Quid est enim absurdius quam mulierem de humili ueste uiro superbire, cui te potius expediret obtemperare candidis moribus quam nigellis uestibus repugnare, quia, etsi te indumentum monachae delectabat, etiam hoc gratius posset marito obseruato exornatoque sumi quam illo inconsulto contemptoque praesumi» (ep. 262,9).

72. «... etiamsi coniugale non viduale voluisset ut acciperes indumentum...» (ib., 10). 
quizá vaya bien con el obispo, pero no con Agustín, es decir, con un hombre pobre, nacido de pobres. Así los hombres han de decir que llevo prendas de valor que no hubiese podido poseer ni en la casa de mi padre, ni en mi anterior profesión secular. No es aceptable. Mi ropa ha de ser tal que pueda darla a un hermano mío, si él no tiene; tal que pueda llevarla con decencia un presbítero, un diácono o un subdiácono. Así es como la quiero, puesto que la recibo para el común. Si alguien me da una prenda mejor, la vendo, puesto que es, además, lo que suelo hacer... Os confieso que me avergüenzo de las prendas de valor que me regaláis, puesto que no van a tono con mi profesión, con esta recomendación que os estoy haciendo, con estos miembros, con estas canas ${ }^{73}$.

El texto es hermoso por lo que revela de la actitud del obispo de Hipona. Además nos hace saber, con un ejemplo concreto, en qué podían consistir los regalos de ropa: un «birro», prenda de la que no se sabe con exactitud en qué consistía ${ }^{74}$. El problema que planteaba a san Agustín el regalo no era que se tratase de un «birro», sino de un birro de valor (pretiosus). Por tanto, cabe admitir que el birro era una prenda de vestir ordinaria de san Agustín y de los clérigos con los que convivía. ¿Pero valía también esto para los monjes laicos? Por ello, el argumento tampoco es decisivo.

Cuando se trata de presentar el modo de vestir de los monjes, se señala la posibilidad de que usaran, además del vestido común del pueblo, el pallium, una especie de capa, al estilo de los monjes de Roma ${ }^{75}$. Marie-Ancilla une al «birro» una túnica de lino ${ }^{76}$.

Antes hablamos de una casi unanimidad de los autores a la hora de negar la existencia de un hábito específicamente monástico. En efecto, no es absoluta, pues de ella se apartan Agatha Mary y A. de Vogüé. Ambos autores sostienen, aunque por razones distintas, que la recomendación de que el hábi-

73. «Mihi ipse, cum sciam commune habere quidquid habeo, nolo talia offerat sanctitas uestra, quibus ego solus quasi decentius utar. Offertur mihi, uerbi gratia, birrus pretiosus: forte decet episcopum, quamuis non deceat Augustinum, id est, hominem pauperem, de pauperibus natum. Modo dicturi sunt homines, quia induo pretiosas uestes, quas non possem habere uel in domo patris mei, uel in illa saeculari professione mea. Non decet: talem debeo habere, quale possim, si non habuerit, fratri meo dare. Qualem potest habere presbyter, qualem potest habere decenter diaconus et subdiaconus, talem uolo accipere; quia in commune accipio. Si quis meliorem dederit, uendo: quia et facere soleo... Fateor enim uobis, de pretiosa ueste erubesco: quia non decet hanc professionem, non decet hanc admonitionem, non decet haec membra, non decet hos canos» $(s .356,13)$.

74. MARIE-ANCILLA, 212 habla de un vestido para llevar sobre otro, de lana, que descendía hasta las rodillas y comportaba un capucho.

75. BOFF, 107; cf. también ZUMKELLER, 91.

76. MARIE-ANCILLA, 212. 
to no llame la atención y la de que los siervos de Dios no pretendan agradar con él no parece implicar la ausencia de un hábito común 77 . La primera considera poco razonable excluir, a partir del texto del parágrafo primero de que nos ocupamos, la existencia de un hábito monástico en el sentido actual, porque lo que subyace a las palabras del santo no es la presentación exterior como tal, sino la intención que movía al siervo de Dios a llevar lo que de hecho llevaba ${ }^{78}$. El segundo entra en la cuestión de forma más positiva. La prueba de que llevaban un hábito específico y distintivo la encuentra en un texto del comentario al salmo 147 en que trascribe las comidillas de quienes, al salir de los espectáculos públicos de la época, topaban con monjes. Es el siguiente:

Concluido el espectáculo del teatro o del anfiteatro, aquella caverna comienza a vomitar la turba de gente libertina. Estos, a veces, reteniendo en la mente las imágenes de su vanidad y alimentando su memoria con cosas no sólo inútiles sino también perniciosas... les acontece ver pasar a siervos de Dios, a los que conocen por su porte exterior, ya sea por el vestido, ya por la cabeza, o los conocen ya de vista y se dicen a sí mismos y a los que les acompañan: «iDesdichados hombres, lo que se pierden!» 79 .

El estudioso benedictino considera que este texto no tiene precio por su mención clara de que los monjes llevaban un hábito distinto, aspecto poco manifiesto en el resto de la obra agustiniana, incluida la Regla ${ }^{80}$. Los monjes se distinguirán por el hábito (vestis) y por la tonsura (capitis) 81 .

Una contribución importante a la calidad del porte exterior es asignada al modo de llevar los cabellos. Sin duda por la fina crítica que hace san Agustín a los melenudos (criniti), como si la santidad pelada tuviera menos valor que la melenuda ${ }^{82}$, también los autores hacen mención de este aspecto ${ }^{83}$.

77. De VoGÜÉ, 3,190.

78. Agatha Mary, 147.

79. «Aliquando, dimisso theatro aut anphitheatro, cum coeperit ex illa cavea evomi turba perditorum, aliquando tenentes in animo phantasias vanitatis suae, et memoriam suam pascentes rebus non solum inutilibus, sed et perniciosis, gaudentes in eis tanquam in dulcibus, sed pestiferis, vident plerumque, ut fit, transire servos Dei, cognoscunt ipso habitu vel vestis vel capitis, vel fronte notos habent, et dicunt apud semetipsos et secum: $\mathrm{O}$ miseros istos, quid perdunt!» (en. Ps. 147,8).

80. DE VOGÜÉ, 5,265. Remite a op. mon. 28,36 (sub habitu monachorum).

81. «si uel...vel es acumulativo y no disyuntivo», anota $(i b$.).

82. Cf. op. mon. 31,39-33,41.

83. Cf. Boff, 107. El autor supone que los siervos de Dios seguían la praxis romana de afeitar la barba y cortar la cabellera como resulta de la efigie de san Agustín del s. VI. AGATHA MARY, 147 introduce en la discusión la Carta 22 de san Paulino de Nola, en que su 


\subsection{Parágrafo segundo}

Del conjunto de la Regla y particularmente del capítulo cuarto se deduce que el monasterio a que va dirigida era un monasterio urbano. Lejos de hallarse en un desierto, los monjes podían entrar en contacto con otras personas, de uno y otro sexo. Como señala $A$. de Vogüé, el último parágrafo del capítulo cuarto se comprende fácilmente en un marco urbano, comprensión que se ratifica con lo que dice a propósito de la lavandería y de los baños ${ }^{84}$. La comunidad de san Agustín no está, pues, separada del mundo, ni localmente ni por exigencias litúrgicas y prácticas ${ }^{85}$. Lo cual no obsta para que en otro sentido aparezca segregada 86.

En ese contexto se coloca el contenido del presente parágrafo. Por él sabemos que no se trataba de un monasterio de clausura, por emplear una terminología moderna ${ }^{87}$. Los monjes podían salir de él y de hecho salían. Lo que no explicita el parágrafo son los lugares a donde podían salir. Pero la Regla misma nos aporta alguna información al respecto. Uno de los destinos era la Iglesia, como indica el parágrafo sexto del mismo capítulo ${ }^{88}$. La iglesia a que se refiere no es la iglesia propia del monasterio, al estilo de la que poseen los actuales, puesto que el monasterio dispone sólo de un oratorio ${ }^{89}$. Pero no era ella el único destino de las salidas de los siervos de Dios. El mismo parágrafo hace referencia a otros lugares posibles, sin especificarlos ${ }^{90}$. El capítulo quinto nos ofrece cierta luz al respecto. En su parágrafo séptimo menciona las salidas a los baños y a cualquier otro lugar a donde hubiera necesidad de ir 91 . Esta expresión tan genérica deja entender que se contemplan varias posibili-

autor defiende una imagen en general descuidada del monje, para señalar que, en cuanto a la actitud general de los monjes, del texto se deja entrever que los de Hipona tendían a errar por la parte del monje Marracino, criticado por san Paulino, más que por la de éste.

84. Cf. De VoGüé, 3,194.

85. DE VoGÜÉ, 3,190.

86. «Se nota a lo largo de la Regla que esta tiene un modelo de vida religiosa segregada, claramente delimitada respecto del "mundo".» (BOFF, 109).

87. El fenómeno no es desconocido en el monacato masculino antiguo. Monasterio de estricta clausura fue el de Isidoro en la Tebaida. De él informa Rufino en su Historia monachorum 17,1-4. Cf. DE VoGÜÉ 3,357-360. En cuanto a las mujeres, véase la información de san Agustín mismo en mor. 1,31,68 y el comentario del mismo autor (2,130-131) que distingue entre clausura pasiva y activa.

88. «... quando ergo simul estis in ecclesia...» (praec. 4,6, 1. 103).

89. «In oratorio nemo aliquid agat...» (parec. 2,2,1.37).

90. «... et ubicumque ubi et feminae sunt...» (praec. 4,6, 1. 103-104).

91. «Nec eant ad balneas, siue quocumque ire necesse fuerit, minus quam duo uel tres» (praec. 5,7, 1. 179). 
dades, además de la ya señalada de asistir a la Iglesia ${ }^{92}$. Cabe pensar en salidas para hacer las compras o vender los productos del propio trabajo ${ }^{93}$, o para llevar la ropa a lavar ${ }^{94}, \mathrm{o}$ incluso para consultar al médico 95 .

No sabemos si a los monjes destinatarios de la Regla les gustaba callejear y, en consecuencia, andaban siempre buscando pretextos para hacerlo ${ }^{96}$. En todo caso, un siervo de Dios fuera del monasterio no debía ser una rara avis. Los que salían de los espectáculos públicos bien podían topar con ellos ${ }^{97}$. Por otra parte, sabemos por la correspondencia agustiniana que no siempre las salidas obedecían a motivos válidos. Por ejemplo, no faltaban monjes que se trasladaban a otras ciudades buscando que un obispo les admitiese en el número de los clérigos, algo que el suyo les negaba ${ }^{98}$. Refiriéndose a las siervas de Dios, el santo critica a aquellas que no paran en sus casas y andan por las de las vecinas curioseando y cotilleando ${ }^{99}$.

El parágrafo aporta todavía un segundo dato: el salir acompañados. $\mathrm{Al}$ respecto la Regla se expresa de dos maneras. En el presente parágrafo se sirve del adverbio simul (a la vez = juntos); en el capítulo quinto, en cambio, refiriéndose a las salidas a los baños públicos o a otros lugares no especificados indica el número mínimo de acompañantes: dos o tres ${ }^{100}$. El empleo del simul, sin especificar número, parece indicar que el legislador se está refirien-

92. La razón es que a ella iría el conjunto de los siervos de Dios. No cabe pensar en que salieran a ella por motivo de oración privada, dado que para esta tenían dentro el oratorio.

93. Tal es el caso que explícitamente contempla el Ordo Monasterii, 8: «Si opus fuerit ad aliquam necessitatem monasterii mitti, duo eant... Si opera monasterii mittantur fratres uendere; ... siue aliquid emant ad necessitatem monasterii...». Cf. AGATHA MARY, 148, que remite también a San Basilio (Regulae fusius tractate, 39; 44,1).

94. En el caso de que no la laven los mismos siervos de Dios, sino que la den a lavanderos: «Indumenta uestra... lauentur, siue a uobis, siue a fullonibus...» (praec. 5,4,1.166-167).

95. Cf. praec. 5,6, 1. 177-178.

96. Cuando san Jerónimo escribe a Eustoquia: «Numquam causa deerit procedendi, si semper, quando necesse est, processura sis» (ep. 22,17; BAC 530, p. 221), probablemente lo hace inspirado en casos concretos.

97. Cf. el texto de en. Ps. 147,8, en nota 79.

98. Cf. ep. 60,1. En ella Agustín se refiere a dos de ellos, a los que califica de peores, por haber desertado del monasterio con ese fin (deteriores... desertores).

99. «Invenis sanctimoniales indisciplinatae... Multae non stant in domibus suis, circumeunt domos alienas, curiose agentes, loquentes quae non oportet...» (en. Ps. 99,13). Aunque quizá no se trate aquí propiamente de mujeres que vivan en monasterios, sino de otras que habían consagrado su virginidad pero vivían en sus propias casas (el texto habla de in domibus suis), respecto de las cuales legisla el concilio de Hipona del 393 (cf. Breuiarium Hiponense 31, CCL 149,42, reproducido en Registri Ecclesiae Carthaginensis Excerpta 44, ib., p. 186).

100. «... Nec eant... minus quam duo uel tres» (praec. 5,7,1. 179-180). 
do a los casos en que tiene lugar la salida de la comunidad monástica en pleno, por ejemplo para las celebraciones litúrgicas. Esta interpretación la avala el hecho de que el mismo adverbio vuelve a aparecer en el parágrafo sexto, indicando ya la presencia en la Iglesia ${ }^{101}$. Teniendo en cuenta que las celebraciones eran únicas y que no cabía que unos siervos de Dios asistiesen, por ejemplo, a una Eucaristía y otros a otra, el precepto de salir a la vez o juntos, pudiera parecer innecesario: no quedaba más remedio que salir a la hora de la celebración. Pero es precisamente el hecho de parecer innecesario lo que da fuerza al precepto. San Jerónimo había seguido el mismo camino 102 .

Respecto al salir acompañados de otro $u$ otros dos hermanos, L. Cilleruelo señala el contraste entre la norma agustiniana y la praxis que se percibe en la época ${ }^{103}$. Una prueba clara la ofrecen los giróvagos a los que él censura con severidad en su obra sobre el trabajo de los monjes ${ }^{104}$.

\subsection{Parágrafos tercero, cuarto y quinto}

De estos tres parágrafos se puede decir que aportan más al conocimiento de la psicología humana que al de la historia del monacato. Se ha querido entrever en su contenido una humanidad muy simple, cuya buena voluntad debía ser ayudada por una presencia vigilante y por consideraciones elementales. El método represivo y las instrucciones rudimentarias se explicarían por los datos sociológicos. «El origen modestísimo de la mayor parte de los monjes explica sin duda el nivel cultural y moral poco elevado en que se colocan las medidas tomadas por la Regla para proteger la castidad»105. L. Cilleruelo, al contrario, juzga que el contenido de estos parágrafos no constituye una doctrina general, sino que obedece más bien a algunas experiencias lamentables, difíciles de explicar ${ }^{106}$. En todo caso, el texto tiene su significado en la

101. «Quando ergo simul estis in ecclesia et ubicumque ubi et feminae sunt...» (praec. 4,6, 1. 103-104). Cf. Posidio, Vita Augustini; 15; SAGE, 226; DE VoGǘ́, 3,190.

102. Ep. 108,20. En la comunidad de Paula los tres grupos salían juntos, cada uno guíado por su superiora particular. Cf. DE VoGÜÉ, 3,190.

103. «La norma de que los hermanos no salgan de casa solos no parece hallar correspondencia en la legislación de aquella época. Los monjes viajaban individualmente, llevando cartas de una parte a otra, por asuntos familiares, públicos o privados; intervenían individualmente en los negocios y polémicas, y eran elegidos para los puestos clericales» (Cilleruelo, Comentario, 341-342).

104. Ib. Cf. op. mon. 28,36 .

105. DE VOGÜÉ 3,190-191.

106. Cilleruelo, Comentario, 347. Agatha Mary, por su parte, ve detrás de estos parágrafos una de las consecuencias de la expansión del monacato, que llevó consigo una fuen- 
historia del monacato occidental. Baste poner los ojos en los monjes de Vercelli a los que se les prohibía encontrarse con mujeres 107.

\subsection{Parágrafo sexto}

El presente parágrafo aporta dos datos sobre la vida concreta de los siervos de Dios del monasterio al que va dirigida la Regla: sus salidas a la iglesia o a otros lugares. Como ya hablamos de ello, no procede detenerse más en el hecho en sí.

Pero el primero de los datos plantea dos cuestiones. De una parte, el lector quisiera saber más detalles sobre la presencia de los siervos de Dios en la iglesia; de otra, ante la sorpresa que le produce el advertir que se considera a la iglesia como un lugar peligroso para la castidad de los siervos de Dios, quisiera saber en qué circunstancias se producía dicha presencia.

Respecto a lo primero, comenzamos recordando que no se trata de una iglesia que pertenezca al monasterio, sino de la Basilica Pacis -la catedral de Hipona- o de cualquier otro templo en que tenían lugar los cultos litúrgi$\cos 108$. En segundo lugar, hay que suponer que los siervos de Dios de Hipona asistían a diario, a diferencia de lo que ocurría en otros lugares ${ }^{109}$, a la celebración eucarística. Hay que suponerlo, de una parte, porque no consta explícitamente en ningún texto y, de otra, porque, conocida la insistencia del santo en la recepción diaria de la Eucaristía, no cabe pensar que dispensase de ella a los siervos de Dios. En tercer lugar, algunos textos parecen indicar que ellos asistían también al oficio divino 110 .

¿Qué contexto justifica el que los siervos de Dios hayan de proteger recíprocamente su castidad cuando coinciden en la iglesia con mujeres? No tenemos constancia de que hubieran existido escándalos en que estuvieran

te de debilidades. De ella es prueba el número de monjes y monjas que abandonaron sus monasterios y que constituyó un problema serio y provocó que el tema fuera tratado en diversos concilios (cf. AgATHA MARY, 152-153).

107. Ambrosio, ep. 63,82.

108. La obra de Agustín nos revela la existencia de media docena de templos urbanos o suburbanos. Cf. al respecto. V. SAXER, Ippona, en Dizionario patristico e di antichità cristiane, Casale Monferrato 1983, p. 1802, con bibliografía para una información ulterior.

109. Cf. JERÓNIMO, ep. 108,20.

110. «Acta sunt uespertina quae cotidie solent, nobisque cum episcopo recedentibus, fratres eoden loco hymnos dixerunt non parua multitudine utriusque sexus ad obscuratum diem manente atque psallente» (ep.29,11). Todo ello supuesto que bajo fratres (hermanos) haya de entenderse a los siervos de Dios, que no está claro. 
envueltos siervos de Dios del monasterio agustiniano. Pero sobre la cuestión pueden arrojar algo de luz varios textos de san Agustín mismo ${ }^{111}$.

En dos de ellos es significativo que el santo aduzca como ejemplos pecados cometidos, de hecho, en el recinto de la iglesia. En el primero, habla de un adulterio: «Si optases por cometer un adulterio dentro de estas paredes, ¿habría alguien más criminal que tú?» ${ }^{112}$. Es cierto que el ejemplo puede ser puramente teórico. Pero otro texto que se encuentra en una de las cartas descubiertas por J. Divjak parece descender más a la realidad. El obispo de Hipona plantea la cuestión de si la Iglesia ha de castigar ciertos pecados ${ }^{113}$, cuando las autoridades civiles se inhiben por la naturaleza del caso. Él se muestra favorable, argumentando de esta manera:

Aunque si, poseyendo el honor propio de la curia o del foro, como parece tenerlo ese de quien se trata, quisieran bailar en la Iglesia, no veo cómo podrían perdonarlos los que con vistas a eso tienen en sus manos el poder de imponer el castigo de los azotes. Y, ciertamente, es mucho más grave someter a la propia liviandad la profesión de santidad que atreverse a danzar dentro de los muros de la Iglesia 114.

Aunque se trata sólo de una hipótesis, el hecho de que la plantee sugiere que podía darse ${ }^{115}$. La continuación de la carta es todavía más explícita:

... de lo contrario, si nos dejamos impresionar sólo por sus quejas cuando reciben el castigo físico, y no nos afectan sus acciones cuando infligen a Dios una afrenta impía y con su inquieta maldad perturban la paz y el decoro de la honestidad y santidad de la iglesia; o, si nos sentimos afectados por las mismas maldades que hombres perversísimos perpetran con nefanda osadía en la iglesia... 116 .

111. Cf. MARIE-ANCILla, 135 , que remite a ep. $13^{*}, 14^{*}, 15^{*}$.

112. «Si eligeres in ecclesia facere adulterium intra istos parietes, quid te esset sceleratius?» $(s .82,11,14)$.

113. En concreto se trata de un estupro cometido sobre una monja que había hecho profesión de santidad: «... quia difficile mihi uidentur qui eum repererunt cum illa femina quam professam sanctimonialem ad ludibrium stupri de patria duxerat ab eius corporali iniuria temperasse» $(e p .9 *, 1)$.

114. «Quamquam si, cum honorem uel curiae uel fori habent, quem uidetur habere iste de quo agitur, in ecclesia saltare vellent, non uideo quomodo eis possent parcere qui propter hoc etiam in manibus ferunt, unde disciplinam uerberum imponunt: et utique multo est gravius sanctitatis professionem libidini suae subdere quam intra ecclesiae parietes audere saltare» $(e p .9 *, 2)$.

115. La fecha de la carta es tardía (h. el 422), pero cabe que esa hipótesis esté formulada sobre experiencias anteriores, como la que señalamos a continuación.

116. «... alioquin si querelis eorum mouemur, quando corporalem accipiunt disciplinam, nec mouemur factis quando deo faciunt impiissimam iniuriam et inquietissima nequi- 
El texto refleja bien a las claras cómo la iglesia podía convertirse en un lugar de inmoralidad 117.

Otro pasaje aun más explícito lo ofrece uno de los nuevos sermones del santo editados por F. Dolbeau, que aclara en parte lo anterior. En él se felicita el predicador porque, gracias a que se han tomado las medidas oportunas, ya no tienen lugar dentro del recinto del templo las inmoralidades de otros tiempos, de las que él mismo fue testigo y protagonista. Es el siguiente:

En efecto, qué relajo y mezcla de machos y hembras hubo antes aquí, todos lo conocemos porque incluso yo en edad pasada fui parte de esta infamia. Mediante su siervo (el obispo Aurelio) el Señor hizo que a las vigilias asistiesen sin entremezclarse varones y mujeres. Cuando estudiaba yo en esta ciudad, al asistir de niño a las vigilias anduve así vigilante respecto a las hembras entremezcladas con la desvergüenza de los machos, donde quizás hasta la ocasión tentaba a la castidad.

¡Qué honestamente se asiste ahora a las vigilias, qué castamente, qué irreprochablemente! Este esmero no podrá desagradar ni a los mismos contra quienes se ha establecido. Los infames, los insolentes, los insidiosos de la castidad ajena pueden lamentar este esmero, no pueden censurarlo. Pero ¿sólo esto ha sucedido como causa quizás única de mi gozo? ¿Qué decir de los diversos accesos e ingresos? ¡Cómo se procuró, con cuánta prudencia se consiguió, con qué constancia se logró que, quienes una vez dentro habían de estar en lugares separados, entrasen por vías también diversas, no fuese que, por entrar apretujándose, diesen inicio, siervos infames y descarados, a lo que después intentarían llevar a cabo! 118: jlas cosas que ellos suelen espetar a la cara a las señoras que pasan! ¡Cuán diligentemente se vio esto, con qué vigor se le opuso resistencia! Si recordamos cuántas cosas solían suceder en la iglesia napaliense, donde la memoria del dichoso obispo y mártir Cipriano, quizás aún nos lamentaremos: si lo olvidamos, damos a Dios menos gracias. Tráigalo a la memoria conmigo vuestra caridad, hermanos; recuerdo los beneficios que Dios os ha hecho mediante vuestro obispo: donde otrora hacían mucho ruido cancioncillas descaradas, resue-

tia decus honestatis et sanctitatis ecclesiae quietem perturbant, aut $s i$ «sic $>$ mouemur ipsis malefactis nequissimorum hominum in ecclesia nefandis ausibus perpetrant...» $\left(e p .9^{*}, 3\right)$.

117. E incluso permite suponer que el estupro de que habla se perpetró dentro de las paredes de la iglesia. Tanto más que la propuesta de castigo que propugna el santo es en defensa de la casa de Dios: «... quae sententia proferenda sit aduersus dei seruos qui pro domini sui domo faciunt aliquid scelerati incomparabiliter minus quam paretur legibus publicis...» (ep. $9 *, 3)$.

118. Los apretujones que tenían lugar a la entrada de la Iglesia, cuando la puerta era estrecha, era como el prólogo a una acción que luego tratarían de completar («ne in angusto intrantes inciperent quod postea perficere molirentur»). 
nan ahora himnos; donde la vigilia servía a la lujuria, la vigilia sirve a la santidad; por último, donde se ofendía a Dios, se aplaca a Dios 119.

Las reformas introducidas por el obispo de Cartago para evitar la inmoralidad en el interior del templo son dos: la prohibición de cantos y danzas en las iglesias y la separación de los sexos, algo -esto último- que parece representar una novedad ${ }^{120}$. Aunque el sermón está predicado en Cartago y se trata de costumbres que ya habían desaparecido, hay que tener en cuenta que está fechado hacia el 403-404 121, es decir, sólo un poco después de la fecha de composición de la Regla. Hay que tener en cuenta también que el mismo texto indica que dichas prácticas existían o, al menos, habían existido en otros lugares. En todo caso, el pasaje nos muestra el contexto en que en algunos lugares se habían desarrollado determinadas celebraciones litúrgicas, nada

119. «Quae hic enim antea fuerit dissolutio et confussio feminarum et masculorum, omnes nouimus, quia et nos in praeterita aetate huius labis pars fuimus. Factum est a Domino per seruum suum ut permixtus sexus non vigilaret. Ego puer uigilans cum studerem in hac ciuitate, sic uigilaui feminis permixtis improbitatibus masculorum, ubi forte et castitatem temptabat occasio. Quam nunc honeste uigilatur, quam caste, quam sancte! Haec diligentia nec ipsis contra quos instituta est poterit displicere. Ipsi improbi, ipsi petulantes, ipsi insidiatores castitatis alienae hanc diligentiam dolere possunt, culpare non possunt. Sed hoc solum factum est, ut hinc solum forte gauderemus? Quid de diuersis aditibus et ingressibus? Quomodo curatum est, quanta prudentia inuentum, quanta instantia perfectum, ut illi qui, cum ingressi essent, discretis locis futuri erant, etiam per discreta ingrederentur, ne in angusto intrantes inciperent quod postea perficere molirentur, serui improui et impudentes, quae solent dicere in frontem transeuntium matronarum. Quam uigilantes ista uisa sunt, quo uigore sublata» (s. Mainz 5,5, en Augustine d'Hippone, Vingt-six Sermons au peuple d'Afrique, Paris 1996, p. 330. La traducción, salvo algún detalle, es de José Anoz, en Revista Agustiniana 37 (1996) pp. 806-807, quien da razón en las notas de la dureza de algunas expresiones que pueden parecer groseras).

120. Como la atestigua la arqueología cristiana del norte de Africa: «Comme je le rappelle par ailleurs, on peut évaluer à au moins 400 les églises fouillées en Afrique. Sur ce nombre, au moins une centaine sont assez bien conservées ou attentivement fouillées pour qu'on puisse connaître avec une relative précision leur organisation interne; une veintine de cathédrales ont été identifiées avec plus ou moins de vraisemblance. Je ne vois nulle part de trace de séparation matérilisée de catégories de fidéles (c'est-á-dire transversales à l'axe) comme il peut en exister dans les églises de Syrie du Nord. J'ai regroupé un certain nombre d'exemples de barrières dans un des bas-côtés mais je les interprete comme la protection d'un circulation du clergé... Je ne vois donc pour ma part aucune preuve d'une séparation générale et durable des sexes dans les églises africaines» (N. DuvAL, Commentaire topographique et archéologique de sept dossiers des nouveaux sermons, en Augustin Prédicateur (395-411). Actes du Colloque International de Chantilly (5-7 Septembre 1966), ed. par G. Madec, Institut d'Études Augustiniennes, Paris 1996, 171-200: 192.193). No obstante, san Agustín hace referencia a esa separación en ciu. 2,28.

121. Ib. pp. 318-326. 
favorecedor de la castidad, y cabía dentro de lo posible que tales costumbres pudieran reaparecer, incluso en Hipona ${ }^{122}$.

Una afirmación del predicador Agustín en otro de los sermones editados por F. Dolbeau merece ser tomada también en consideración. Dice: «Cuando tenemos el corazón en lo alto, habitáis conmigo donde la gente no se apretuja» 123 . Esto hace presuponer que ya fuera por las reducidas dimensiones del templo, ya porque, aunque fuese espacioso, la afluencia de gente había sido mayor, el contacto físico entre las personas era frecuente, habida cuenta, por otra parte, que los hombres y mujeres no estaban localmente separados.

A todo esto cabe añadir todavía el conocido texto del libro tercero de las Confesiones en que el santo confiesa que, durante la celebración de una de las solemnidades anuales y dentro del recinto de la Iglesia, osó ceder a la concupiscencia y procurarse frutos de muerte 124.

Datos en la misma dirección nos llegan también de otras fuentes de la época, aunque no referidas al norte de Africa. Vigilancio, a quien hizo célebre san Jerónimo por el violento escrito que le dedicó por su oposición a ciertas prácticas litúrgicas y ascéticas, sostenía, a propósito de las vigilias, que eran ocasión de pecado para jóvenes de uno y otro sexo ${ }^{125}$. Y el mismo san Jeró-

122. En ep. 22,1,3 indica cómo la Iglesia de Hipona, respecto de las cubilia et impudicitiae, se había mostrado más intransigente que a propósito de los banquetes en la Iglesia. Pero el hecho mismo de que hubieran tenido que llegar a esa intransigencia advierte sobre la situación social. En un sermón anterior al año 400 señala que determinado tipo de inmoralidad sexual había desaparecido casi por completo: «Ad Hipponam nostram, ubi iam talia pene defecerunt, turpes istae personae de vestra civitate ducuntur» (s. $301 \mathrm{~A}, 7)$.

123. «Quando habemus "sursum cor", illic nobiscum habitatis, ubi nemo se premit» ( $s$. Mayence 63 [Dolbeau 27],2, p. 311); «Ex his igitur multitudinibus exaggerati sunt, quibus per Pascha sic referciuntur ecclesiae, ut turbas ipsorum parietum recuset angustia» (en. Ps. $30,2,2,2)$.

124. «Ausum sum etiam in celebritate sollemnitatum tuarum intra parietes ecclesiae tuae concupiscere et agere negotium procurandi fructus mortis» (conf. 3,3,5). El texto, antes oscuro, recibe ahora luz del anteriormente trascrito. Pero no todos los autores interpretan el texto en este sentido. "It is precisely in this context, focused exclusively on "curiosity", not sexuality, that Augustinus tell us that, even in church, he "dared to desire (concupiscere) and to carry out business (agere negotium) for procuring the fruit of death". Everyone I have seen comment on that expresion assumes that Augustine meant he was making a sexual assignation; but study of this metaphors shows clearly that concupiscere can take the form of "curiosity", exactly as the image-context suggests; it is far more likely, then, that he is telling us that he was making some kind of secular business deal (negotium), probably to advance his rethorical career. And so another brushstroke in the portrait of Augustine, prince of roués, has to be erased» (ROBERT J. O'CONNELL, Images of Conversion in St. Augustine's Confessions, New York 1996, p. 32).

125. Jerónimo, Contra Vigilantium, 9. Cf. A. de Vogüé quien añade cómo curiosamente de esta imputación se hace eco el canon 35 del concilio de Elvira, de principios del 
nimo da el siguiente consejo a Leta, a propósito de la educación de su hija Paula, consagrada al servicio de Cristo ya desde antes de su nacimiento:

A las basílicas de los mártires y a las iglesias no vaya si no es con su madre. Que ningún joven, ninguno de esos tipos que llevan tupé la sonría. Los días de vigilia y las solemnes veladas nocturnas los celebrará de tal modo nuestra virgen, que no se aparte ni una pulgada del lado de su madre ${ }^{126 .}$

\section{Lectura ascético-espiritual}

Nos ocupamos únicamente de la primera parte del capítulo (par. 1-6), dejando para otro momento la segunda. Lo que ofrecemos es una síntesis de lo que han dicho otros comentaristas.

\subsection{Planteamientos generales}

Comenzamos con algunas apreciaciones de los distintos autores a un nivel puramente formal.

En este capítulo se echa de menos un cierto orden sistemático ${ }^{127}$ y sorprende que, a diferencia de los demás en que hay una clara secuencia de ideas, ninguna de sus líneas de pensamiento se desarrolla plenamente hasta alcanzar una neta conclusión; las ideas se interrumpen y, aunque algunas sean recuperadas de nuevo, otras quedan inconclusas. Este particular se valora como indicador de la complejidad de los temas y de que no puede haber respuestas taxativas a los problemas considerados 128 .

s. IV. Este, después de haber condenado el encendido de cirios, «prohibe que las mujeres velen toda la noche en los cementerios porque con frecuencia cometen ocultos scelera bajo pretexto de oración» (DE VOGUÉ, 5,103). También san Juan Crisóstomo advertía sobre los peligros de las vigilias para las vírgenes con estas palabras: «Es necesario apartar (a las vírgenes) de los funerales y las vigilias. Pues aquella astuta serpiente sabe también sembrar su veneno por medio de acciones virtuosas. La virgen ha de estar defendida por todas partes y ha de salir de casa rara vez a lo largo de todo el año, cuando razones inexorables y necesarias lo exijan» (J. CRISÓSTOMO, Diálogo sobre el sacerdocio 3,13. Introducción, traducción y notas de J. J. Ayán Calvo y P. de Navascués Benlloch, Madrid 2002, p. 107).

126. «Basilicas martyrum et ecclesias sine matre non adeat. Nullus ei iuuenis, nullus cincinnatus adrideat. Vigiliarum dies et sollemnes pernoctationes sic virguncula nostra celebret, ut ne transuersum quidem unquam a matre discedat» (ep. 107,9).

127. L. Cilleruelo, Comentario, 370.

128. AGATHA MARY, 157.161. 
A nivel de contenido, se juzga que el capítulo presenta a los monjes en un punto en que la presencia del pecado ha de ser tomada en serio, y que no lo hace desde un planteamiento teórico sino desde situaciones que se pueden dar en el grupo al que se dirige el legislador ${ }^{129}$.

Que el capítulo cuarto de la Regla tiene la castidad consagrada como tema propio o, en todo caso, que aparece en el trasfondo, es admisión común, como ya se indicó con anterioridad. Se ve en él un punto extremadamente delicado y difícil de la Regla, no por el tema en sí, sino por el modo como es tratado. Cuando se lee todo de una vez -se afirma-, la sensación que queda es extraña y pesada ${ }^{130}$. $\mathrm{Y}$ en este contexto procede recordar las peculiaridades del capítulo anotadas en el primer apartado, dado que buena parte de ellas tienen aquí su fundamento.

Pero esa misma admisión plantea el problema, percibido y expresado por la gran mayoría de los autores, de la falta de una terminología apropiada. Advierten la falta de términos como celibato, castidad perfecta o consagrada, virginidad, continencia, etc. ${ }^{131}$. Al mismo tiempo, constatan la falta de una teología específica del celibato o virginidad consagrados ${ }^{132}$. En la misma línea, ponen de relieve, de una parte, que la Regla ve la castidad sólo desde el punto de vista ascético, sin ofrecer las motivaciones positivas y profundas, el para qué 133 ; de otra, que se limita a hablar de la custodia de la castidad y no del voto ${ }^{134}$. Como echan de menos una presentación positiva y personal de la virginidad de la que no quieren privar a sus lectores, los comentaristas recurren a otras obras del santo 135 .

129. Agatha MaRy, 166.

130. BOFF, 101.

131. Le célibat, 44 NA I,108; BofF, 103; L. Cilleruelo, Comentario, 341. L. Verheijen habla del estupor que produce el hecho, sobre todo comparado con otros textos como $s$. uirg. y varios sermones sobre la Iglesia madre (ib. 45 NA I,109).

132. ZUMKELLER, 75, quien señala, no obstante, que el alto valor que el santo otorga al celibato consagrado lo permiten atisbar las consideraciones del capítulo; TrAPĖ, 145; BOFF, 103 siguiendo de cerca a L. Verheijen (NA I,107-150); AGATHA MARY, 153: «There is no "theology of celibacy" in what he wrote, just as there is no developed treatment of prayer in chapter II. Like prayer, chastity and celibacy are subsumed in the very fact that monks are monks... he is not writing about celibacy, he is writing to celibates about behaviour that befits their calling» (ib. 153-154).

133. BOFF, 104.

134. SAge, 223; A. MANRiQue - A. SAlas, 157; Trapè, 145, sin dedicarle, añade, un capítulo, a diferencia de lo que hace con la pobreza y obediencia; VAN BAVEL, 58; F. MORIONES, Espiritualidad agustino-recoleta II, 257.

135. «Mais on trouve qu'il aurait pu parler autrement à propos du célibat de ces moines. Les lecteurs ne se rendent pas compte du fait qu'il s'est effectivement exprimé autrement ailleurs. Son De sancta virginitate, par exemple, et ses Sermons sur l'Église Vierge lais- 
Los juicios que acabamos de emitir dependen en buena medida de otros similares de L. Verheijen. Este sabio agustino subraya el extraño proceder del legislador en la Regla: con relación a lo que luego serían los votos de pobreza y obediencia, expone su ideal en los capítulos primero y séptimo respectivamente; en cambio, el voto de castidad se limita a presuponerlo sin presentar ni el ideal ni motivación alguna 136.

A la doble constatación los autores buscan una razón. A nivel general ponen de relieve que san Agustín se muestra como hijo de su tiempo ${ }^{137}$. A nivel doctrinal, se ha ocupado detenidamente de ambas cuestiónes L. Verheijen, quien cree haber hallado la explicación. Según él, en el 397 san Agustín no podía presentar ideal alguno de la castidad consagrada o celibato, porque aún no lo había alcanzado personalmente. De hecho, la lectura de las obras del santo escritas entre el 386 y el episcopado (395 ó 396), y el análisis de sus textos sobre el celibato y el matrimonio le produjo un desencanto: no halló nada sobre la motivación del celibato, y sobre el matrimonio, sólo ideas que más tarde rechazaría ${ }^{138}$. Hasta entonces el santo apenas había reflexionado sobre el celibato; para él era sólo un dato tradicional. Al respecto aún no había llegado a conclusiones personales ${ }^{139}$. El san Agustín de la Regla es un Agustín que apenas ha evolucionado ${ }^{140}$. En definitiva, concluye, esa ausencia

sent tout autre impression que le Praeceptum. Ils devraient donc plutôt se demander pourquoi ce dermièr texte reste tant en deçà du niveau atteint ailleurs. Et puis, il s'étonnent du climat d'indiscrétion, avec ses denuntiations par exemple, qui leur parait désagréablement régner dans la seconde moitié du quatrième chapitre, toujours a propos du célibat» (L. VERHEIJEN, Le célibat, 45 NA I,109; cf. también VAN BAVEL, 58).

136. «Mais ce qui allait devenir plus tard le "voeu de chasteté", ou de célibat consacré, est soulement supposé dans notre quatrième chapitre. Le célibat n'y est nulle part prescrit explicitement. Et puisque la prescription manque, toute présentation d'un idéal manque également. Pourquoi s'engager dans cette genre de vie? Augustin ne le dit pas. Avec le caractère abstrait de ses propos sur l'effronterie du regard, c'est cette absence de toute motivation au debut de ce long passage sur le célibat qui me frappe» (Le célibat, $60 \mathrm{NA}$ I,124).

137. VAN BAVEL, 58; BOFF, 105.

138. «Or en lisant ces textes je n'ai pu qu'être deçu: sur le célibat il n'avait là à près rien; sur l'autre face de la médaille, le mariage, il n'avait guère que des idées qu'Augustin a rejetées plus tard très explicitement» (Le célibat, 61 NA I,125).

139. Le célibat, 61 NA I,125. Cf. también Le De sancta virginitate de saint Augustin et sa structure. Un complément à l'étude de chapitre quatrième, en Augustiniana 32 (1982) 266281: 266 NA II, 178-193: 178.

140. Le célibat, 60-61 NA I,124-125. A continuación examina los textos del santo sobre el celibato en general desde la perspectiva de la motivación (ib. 61-67 NA I,125-131), sobre el celibato de san Agustín mismo (ib.67-74 NA I,131-138) y, finalmente, sobre el matrimonio (ib. 74-85 NA I,138-149). 
de reflexión explica el exordio sorprendentemente brusco del pasaje de la Regla sobre el celibato o, más bien, sobre la lascivia en la mirada ${ }^{141}$. Como consecuencia lógica, lamenta que el santo no hubiera escrito la Regla unos años más tarde ${ }^{142}$. En tal caso, podría haber integrado en ella la valiosa teología presente en la obra sobre La virginidad consagrada, posterior sólo en unos años. Como complemento, aduce otras razones: a) la experiencia maniquea del santo; b) la filosofía platónica que subyace a su pensamiento; d) su experiencia personal ${ }^{143}$. Al carro de estas razones se ha subido algún otro comentarista 144 . Otra forma de justificar el mencionado silencio, que tan intrigante resulta, consiste en juzgar que el legislador consideró innecesario recordar a los siervos de Dios que, en virtud de su profesión religiosa, estaban sujetos a la castidad perpetua 145 .

Como ya indicamos, los comentaristas, impulsados casi todos por motivaciones pastorales y espirituales, no quieren privar a sus lectores de la rica teología del santo sobre la castidad o celibato consagrados que nos es bien conocida ${ }^{146}$. Por ello, después de constatar la laguna, se aprestan a llenarla. Con ese fin recurren a los lugares clásicos del pensamiento agustiniano sobre el tema. En primer lugar, y como es comprensible, al ya varias veces mencionado tratado sobre La virginidad consagrada ${ }^{147}$, de cuya doctrina se pondera la verdad, la modernidad y la belleza ${ }^{148}$; a textos de la Ciudad de Dios ${ }^{149}$, del sermón 61, etc. Subrayan que la virginidad o el celibato consagrados son un carisma y que, en consecuencia, san Agustín previene contra la arrogancia espiritual de creer que está en poder del hombre, cuando es un tesoro que se lleva en vasos de barro ( 2 Cor 4,7) ${ }^{150}$; que espiritualiza al religioso introdu-

141. Le célibat, 85 NA I,149. Y continúa: «Arrivé à ce point, Augustin n'a même pas éprouvé le besoin de dire que les moines auxquels il s'adressait devaient pratiquer le célibat; cela allait soi. Et il n'éprouvait pas le besoin non plus de le motiver en présentant un idéal; sa valeur était évident. Aussi a-t-il commencé ex abrupto en dissant: "Votre regard, bien sûr, peut tomber sur une femme..." " (ib. 85-86 NA I,149-150).

142. Le sigue en esto Boff, 104.106.119 y AGATHA MARY, 153-154.

143. L. VERHEIJEN, Le celibat, 45 NA I,109. Se recuerda el dato de san Posidio de que ninguna mujer puso el pie en su casa (Vita Augustini, 26,3).

144. Cf. BOFF, 104-106.

145. SAGE, 223-224. Sobre todo teniendo en cuenta que a este respecto no cabe el más o el menos, sino únicamente el sí o el no (ib.).

146. TRAPE, 145.

147. Cf. ZUMKELLER, 76; TRAPÈ, 146-147.

148. TRAPÈ, 147; ZUMKELLER, 75: «is one of the best things written on the subject in the patristic period».

149. Por ejemplo ciu, 10,6 (Trapè, 146-147)

150. ZUMKELLER, 75 , que remite a ep. 188,2,6. 
ciéndole en una vida cuasi angélica ${ }^{151}$. En un plano general, hacen ver cómo el santo se aleja del neoplatonismo en un tema en que podía haberse servido fácilmente de él 152 .

Puesto de relieve que san Agustín se muestra en el capítulo como hijo de su tiempo, se proponen entender críticamente este texto juzgado fundante, captar el espíritu que se esconde detrás de sus antiguas prescripciones; en definitiva, ofrecer una hermenéutica que tiene los visos de una «operación rescate», único modo de «salvar el texto» 153 .

\subsection{Parágrafo primero}

Este parágrafo suscita precisiones de tipo filológico en torno al significado de habitus y vestis; además, el término habitus es puesto en relación con otros dos usos del mismo en el primer parágrafo del capítulo quinto, donde el legislador contrapone el habitus de la mente al del cuerpo 154.

No falta la comparación entre lo que prescribe el legislador de Hipona sobre el atuendo exterior y las concepciones de otros autores contemporáneos, comparación seguida de una valoración. En contraste con lo que piensa san Paulino de Nola, la propuesta de san Agustín se ve como una bocanada de aire fresco, en cuanto que no pretende que el siervo de Dios vista como un andrajoso, sino únicamente que no llame la atención por su atuendo ${ }^{155}$. Frente a tradiciones monásticas para las que el aspecto exterior descuidado era el ideal, se juzga que nuestro legislador manifiesta un sano equilibrio: ve tan peligroso preocuparse demasiado del aspecto externo como preocuparse demasiado poco; el vestido ha de ir a tono con el propio estado 156.

En cuanto al modo de vestir del siervo de Dios según la Regla, los autores hacen hincapié en la sencillez y modestia que ha de caracterizarlo, y aducen varias razones que justifican la prescripción. Una de ellas es la praxis del mismo san Agustín, conocida en general por la biografía escrita por san Posi-

151. SAge, 223; A. MAnRiQue - A. SAlas, 157. La idea la recoge luego F. Moriones (Espiritualidad agustino-recoleta, II, 256).

152. V. Grossi, Ascetica del corpo e antropologia nella «Regula ad servos Dei» (cc. 35) di S. Agostino, en Mémorial Dom Jean Grobomont (1920-1986), Studia Ephemeridis «Augustinianum», Roma 1988, 315-320: 319.

153. BOFF, 106-107.

154. Agatha MaRy, 146.

155. Agatha Mary, 147.

156. Zumkeller, 77, que remite a s. dom. m. 2,12,41 y a Posidio, Vita Augustini 22. 
dio y, en algún detalle concreto, por el sermón 356 157. Otras son de carácter moral-espiritual, coincidentes algunas en el fondo, pero diversamente formuladas: aunque «el hábito no hace al monje» 158 , el modo de vestir es una realidad que manifiesta el propósito del corazón 159 o una traducción visible de las disposiciones del mismo ${ }^{160}$; la demasiada atención o el excesivo descuido en el vestir puede provocar jactancia o abyección ${ }^{161}$; el hombre carnal puede trasformar la necesidad del vestido en un objeto de vanidad y de seducción 162; la vestimenta extravagante es una expresión de vaciedad interior y de falta de virtud cristiana ${ }^{163}$. El modo de vestir lo ponen también al servicio de la pureza, aunque él solo no baste ${ }^{164}$, como no basta llevar una prenda humilde, si no va acompañada de la humildad de corazón ${ }^{165}$. En este mismo ámbito, establecen una relación entre la modestia en el atuendo y la modestia moral 166. Para esta última idea hallan apoyo en un texto de la obra La virginidad consagrada en el que san Agustín se refiere a ciertas viudas que prometieron vivir en castidad, pero que conservan el deseo de agradar con un vestido más elegante de lo que exige su excelsa profesión 167.

El motivo de la interioridad aparece dominante en los comentarios al parágrafo. De un lado, una arbitraria organización de los temas contenidos en la Regla permite asociar este primer parágrafo del capítulo cuarto al tercero del capítulo segundo bajo el lema «prioridad de la interioridad» 168 . De otro, la exhortación a agradar con el modo de vivir y no con el modo de vestir se convierte en ocasión para hablar del vestido interior que debe traslucirse en el porte digno de una persona que profesa la santidad o del adorno exterior que va en detrimento del hombre interior ${ }^{169}$; del santo hábito del corazón ${ }^{170}$;

157. Vita Augustini 22 y s. 356,13. Cf. ZumKeller, 77, A. MANRiQue - A. SAlas, 158; BOFF, 107-108; VAN BAVEL, 59.

158. VAN BAVEL, 59.

159. SAGE, 224.

160. MARIE-ANCILLA, 211-212.

161. SA. MANRIQUe - A. SALAS, 158; VAN BAVEL, 59.

162. SAGE, 224: Cilleruelo, Comentario, 339; BofF, 107-108, quien indica que la vanidad es un mal que ataca sobre todo a los jóvenes.

163. ZUMKELLER, 77.

164. A. MANRIQUe - A. SALAS, 157 , donde remite a c. Iul. 5,6,24.

165. MARIE-ANCILLA, 211-212. Tal es su verdadera perspectiva. La encuentra en la ep. 262. 166. VAN BAVEL, 59.

167. S. virg. 34,34. Cf. A. MANRIQue - A. SAlas, 157-158; SAGE, 225; MARIE-ANCILla, 213; VAN BAVEL, 59. Otro texto al que se suele remitir es a ep. 245,1; cf. SAGE, 224; MARIEANCILLA, 213.

168. MARIE-ANCILLA, 211-212. Pe 3,3-4.

169. A. MANRIQUE - A. SALAS, 158 , donde remite a $s .356,13$ y a Gal $3,7,1$ Tim 2,9 y 1

170. Boff, 107-108. 
del buen corazón en contraposición a una elegante presencia exterior ${ }^{171}$; del mayor interés por el bien del espíritu que por la salvaguarda de la pobreza monástica 172 ; de la belleza del hombre interior, más apetecible que los vanos adornos del exterior 173 ; de la del alma, cuyo verdadero adorno son la caridad y las costumbres 174; de un pensamiento de Paula, la corresponsal de san Jerónimo, a saber: «la limpieza del cuerpo y del vestido va unida a la suciedad del alma» 175 .

Para concluir, añadamos que en línea con el porte exterior, algunos autores sacan a relucir el problema de los criniti o monjes melenudos 176 .

\subsection{Parágrafo segundo}

A propósito de este parágrafo, hay quien juzga que el legislador se limita a ordenar lo que era práctica habitual 177 y quien habla de un extraño realismo, vinculado a una situación muy concreta. Este último autor alude al caso de un clérigo que inesperadamente se encontró durmiendo al lado de una mujer, a propósito del cual comenta el santo: «Cierto que tales cosas no ocurrirían fácilmente a los clérigos si no saliesen solos cuando tienen que hacerlo por necesidades particulares o de la Iglesia» 178.

En lo preceptuado en el parágrafo se percibe, en línea con el carácter relativamente cerrado de las comunidades monásticas de entonces, un afán protector ${ }^{179}$ frente a los peligros para la castidad que se pueden presentar en el contacto con la calle ${ }^{180}$. En la propuesta del legislador se ve una invitación a combatir juntos 181 . En el trasfondo de la misma se descubre el gran valor asignado a la comunidad monástica para mantener la pureza del corazón ${ }^{182}$, o la compañía de los hermanos como el clima natural de la pureza ${ }^{183}$. Vinculado a este ámbito aparece también el tema de la fama de los religiosos ${ }^{184}$.

171. VAN BAVEL, 59.

172. ZUMKELLER, 77.

173. SAGE, 224, que remite a ep. 245,1 .

174. MARIE-ANCILla, 213, que remite a $s .161,11,12$, ep. 245, 1 y s. 95,7; Agatha MARY, 147; SAGE, 225.

175. JeRÓNIMO, ep. 108,20; cf. DE VoGÜÉ, 3,189.

176. SAGE, 225; MARIE-ANCILLA, 213;

177. Agatha MARY, 149.

178. Ep.13*3. Cf. Cilleruelo, Comentario, 342.

179. VAN BAVEL, 60.

180. SAGE, 226.

181. SAGE, 226.

182. ZUMKELLER, 79.

183. A. MANRIQUe - A. SALAS, 164

184. CILlERUELO, 306. En esta obra justificaba doblemente la norma: para salvaguardar la fama de los religiosos y «además había que mostrar rigor en los principios de aquel 
Otros autores amplían el horizonte. La comunidad o los hermanos que la forman no son sólo una defensa frente a los peligros contra la castidad; son también una ayuda ante cualquier dificultad en que se encuentren los siervos de Dios en sus salidas fuera del monasterio, ayuda no siempre fácil ${ }^{185}$. El mismo salir juntos es visto como signo externo de fraternidad. Desde esta perspectiva se afirma que la comunión fraterna se vive dentro y fuera de casa: tal sería el espíritu del precepto en cuestión. Los siervos de Dios pueden ser más útiles para el pueblo de Dios con su ejemplo de fraternidad que estando directamente a su servicio. Siempre que se trate de una verdadera comunión y no de un puro gregarismo 186.

Varios autores constatan la diferencia cultural con relación a los tiempos actuales 187 y señalan que lo preceptuado en el parágrafo no puede cumplirse hoy ${ }^{188}$, aunque sí es posible mantener su espíritu. En todo caso, hay que hacerlo vida de otra manera ${ }^{189}$, evitando siempre formar grupos aparte, puesto que la tendencia actual va hacia una mayor integración entre religiosos y pueblo 190 .

\subsection{Parágrafo tercero}

Dos términos se consideran fundamentales en el parágrafo: «ofender» (offendere) y la santidad (sanctitas). De ellos, el primero ha recibido menos atención que el segundo. Es praxis común ponderar la «santidad», por supuesto la del estado monástico ${ }^{191}$, como criterio que ha de regular la vida del siervo de Dios fuera del monasterio. Se señala que el obispo de Hipona califica de «santa» la virginidad y se aduce la razón: él santo juzga la continencia perfecta por el Reino como «una santidad superior a la del matrimonio», pues ve

monacato; para obtener un resultado mediocre o mínimo, no valía la pena levantar monasterios». Cf. también Cilleruelo, Comentario, 342.

185. Agatha MARY, 149.

186. BOFF, 108.

187. BOFF, 109; VAN BAVEL, 60.

188. Zumkeller, 79; van Bavel, 60; Cilleruelo, Comentario, 342.

189. «... por ejemplo, cuando alguien está ausente por un tiempo más largo y nadie sabe dónde se encuentra, hay una falta de sentido común y de un clima de confianza mutua» (VAN BAVEL, 60). «But what the lawgiver has in mind when he sets down this prescription remains permanently valid: We should avoid separating ourselves from the community and traveling ways of our own which are kept a secret from others and specialliy from superiors» (ZUMKELLER, 78).

190. BoFF, 109.

191. SAGE, 226. 
en la virginidad el más alto grado de santidad, contexto en que se manifiesta la íntima vinculación entre castidad y humildad ${ }^{192}$. La santidad vinculada a la virginidad confirma y hace más luminosa la santidad del bautismo 193.

Agatha Mary ve en el «ofender» (offendere) una clave de lo que realmente está en juego en esta parte de la Regla. Pero, a la hora de traducir el término, lo refiere a la ofensa ( «give offense») verbal. La autora piensa en una palabra atrevida y de ataque que implica, más allá de las debilidades momentáneas, una actitud que deliberadamente rompe las convenciones y standars aceptados ${ }^{194}$. Insiste en que no se trata de pura cortesía pues, además del adecuado porte exterior, reclama la integridad interior, si el monje ha de ser identificado con el estilo de vida que ha emprendido 195 .

Hay quien interpreta el verbo «ofender» en el sentido genérico de no resultar «llamativos» en el porte ${ }^{196}$, y quien entra en más detalles: implicaría no ofender la mirada de terceras personas con vulgaridades, risas estrepitosas, griterías, palabras groseras, embravecimientos 197 . Hallan apoyo para su interpretación en este texto de la obra La virginidad consagrada:

... incluso aquellos pecados que son o se juzgan más leves, ni se hallan ni se encuentran en vosotros: el descaro en el rostro, el mariposear de los ojos, el desenfreno de la lengua, la risa provocadora, el chiste grosero, un vestir indecoroso o un andar afectado o disoluto 198.

El comportamiento «no ofensivo» que reclama el legislador es visto como ejercicio de caridad, como servicio a la edificación del prójimo y, al mismo tiempo, como propaganda del monacato ${ }^{199}$. Por eso los siervos de Dios

192. MARIE-ANCILLA, 214. Remite a b. uid.9,12;11,14; s. uirg. 21,21;30,30; 56,57; s. 304,2.

193. TRAPE, 149.

194. Agatha Mary, 150. Sigue diciendo: «This partly explains the severe note of much of what Augustine wrote in this chapter. Much more is at stake than garded behaviour. Agustine is concerned with the monk's attitude to an important part of the whole being of each member» (ib.).

195. Agatha Mary, 150. Que supera el nivel de la simple educación lo señala también BOFF, 109.

196. MARIE-ANCILLA, 214.

197. BOFF, 109; TRAPÈ, 151.

198. «... verum etiam illa quae leviora vel sunt, vel putantur, non inveniuntur nec oriuntur in vobis; non improbus vultus, non vagi oculi, non infrenis lingua, non petulans risus, non scurrilis iocus, non indecens habitus, non tumidus aut fluxus incessus» (s. uirg. 53,54).

199. Cilleruelo, 308. El autor continúa: «El hombre no sólo es padre de sus obras, sino también hijo de las mismas. He aquí una triple misión de Fray Ejemplo en la frontera, fuera de la frontera y dentro de la frontera» (ib.). 
han de convencerse de que no es indiferente la imagen que den 200 y de que su conducta debe recomendarles ante quienes los ven ${ }^{201}$. Se trata, pues, de que los siervos de Dios sean conscientes de las exigencias eclesiales y sociales de la propia conducta ${ }^{202}$. Positivamente, eso implica el propósito de llegar a ser el buen olor de Cristo de que habla el capítulo octavo de la Regla 203; negativamente, el evitar ser escándalo para el hermano, aunque entendido en términos genéricos 204 .

No faltan quienes vinculan más específicamente el parágrafo al ámbito de la castidad, en función de la cual se ha de disciplinar el cuerpo en todos sus movimientos 205 : Respecto a la mirada se la considera más en un sentido activo (mirar), que pasivo (ser objeto de miradas) ${ }^{206}$. En otros términos, se asume que el legislador prescribe la modestia 207.

La norma se valora como oportuna $208 \mathrm{y}$, a pesar del paso del tiempo, permanente. Se la ve fundamentada en el sentido profundo de la consagración a Dios y en la intuición segura que tienen el pueblo cristiano y la persona consagrada 209 .

\subsection{Parágrafo cuarto}

El presente parágrafo concentra al máximo la atención de los comentadores del capítulo.

200. ZUMKELLER, 78

201. AGATHA MARY, 149

202. BoFf, 110 , quien trae a colación el pensamiento agustiniano que reclama a la vez buena conciencia, para uno mismo, y buen nombre, para los demás $(s .355,1)$.

203. ZUMKELLER, 78; SAGE, 226; BOFF, 110.

204. Boff, 111, que cita Rom 14,13 y b. uid. 22,27. «El religioso, la religiosa, permitásenos decirlo, es como la "mujer del César": No sólamente ha de estar exento de culpa, sino inclusive de sospecha de culpa. No basta ser evangélico; es necesario también parecerlo» (ib.).

205. Sage, 226; A. ManRiQue - A. Salas, 159; Cilleruelo, 314: «Hay un cierto género de vanidad o exhibicionismo que es ya un disfraz de la concupiscencia, aunque parezca mera frivolidad. La coquetería es un arte de la provocación, una inducción al pecado y añade a los delitos carnales la malicia del escándalo».

206. A. Manrique - A. Salas, 159; Cilleruelo, 308, que habla de la guarda de los sentidos.

207. TRAPE, 149. «Da questa duplice intuizione (del pueblo cristiano y del alma consagrada) nasce il dovere e la misura della modestia, che evita quanto può offendere il sentimento altrui e pone in opera quanto corrisponde al sentimento proprio» (ib.).

208. A. MANRIQUE - A. SALAS, 159.

209. TRAPE, 149. 
Comenzamos nuestra síntesis por unas consideraciones de carácter general. La primera se refiere a la impresión de shock que, según una autora, produce. A su parecer, el paso de los tres primeros capítulos a este parágrafo equivale a entrar en otro mundo con valores, pensamientos y costumbres diferentes de los habituales ${ }^{210}$. La segunda, a la actitud de san Agustín respecto a la mujer, actitud que varios autores tratan de defender, colocándola en su propio contexto histórico y social ${ }^{211}$. La tercera, a la importancia de lo tratado en los parágrafos 4-9: se considera que dicha importancia no está en los actos de un determinado monje, sino en el comportamiento de la comunidad frente a él ${ }^{212}$. La última, a la necesidad de poner aparte nuestra comprensión de los temas, puesto que la relación entre el amor y el sexo en su sentido metafísico es un hallazgo posterior a san Agustín. Lo que importan, se dice, son sus puntos de vista teológicos 213 .

El parágrafo parte del supuesto de que el monje, por su libre compromiso anterior, ha perdido la libertad para comportarse en el ámbito sexual como el común de los humanos ${ }^{214}$. Se anota que su castidad es referida a su lado práctico, quedando reducida a la disciplina del mirar, aunque se añade que todo ello hay que situarlo en el marco más amplio de la teología de la virginidad que el santo desarrolla en escritos posteriores ${ }^{215}$. Más en concreto, se toma nota de las diversas posibilidades que san Agustín contempla en cuanto al hecho y en cuanto a los modos. En cuanto al hecho, se pone de relieve, primero, la distinción neta que se establece entre el ver y el dejar los ojos prendidos en una mujer ${ }^{216}$; después, que no sólo contempla el desear (adpetere), sino también el estimular una respuesta (adpeti velle) ${ }^{217}$, que en el caso concreto incluye una pasión consentida y correspondida, que va más allá de un simple intercambio mutuo de miradas ${ }^{218}$. En cuanto al modo, se indica que esta pasión se puede estimular de múltiples maneras: con las miradas, con el

210. Agatha Mary, 151.

211. L. VERHEIJEN, Le célibat, 56-59 NA I,120-123: «Augustin a toujours eu la plus grande estime pour la femme en tant que telle» $(i b .55$ NA I,120); Cilleruelo, Comentario, 346.349; BoFF, 105, que remite a b. coni. 17,19; uera rel. 41,78; ep. 243.

212. AGATHA MARY, 190. La autora presenta también la hipótesis de que san Agustín esté haciendo frente a posibles desastres existentes en la comunidad, con medidas y palabras duras, aunque justas si van acompañadas de misericordia y compasión (ib.156).

213. AGATHA MARY, 157.

214. AGATHA MARY, 152.

215. BofF, 112, que remite a s. uirg., ciu. y b. coni.

216. SAGE, 227, que remite a Lc 11,34; Jb 31,1; en. Ps. 50,3; A. MANRIQUe - A. SAlas, 112. 159.

217. Agatha MARY, 155.

218. BOFF, 115. 
tacto y con el movimiento del corazón ${ }^{219}$. Se quiere dejar claro que no se trata del contacto normal con una persona del otro sexo, sino del deseo de poseerla sexualmente, que se expresa también por medio de los ojos ${ }^{220}$. En definitiva, se entiende que la Regla estigmatiza una forma particular de concupiscencia de la carne 221.

Del hecho de que el legislador se centre en la mirada, los comentaristas ofrecen diversas explicaciones. Una de ellas, es la relación que establece el mismo san Agustín entre ojo (oculus) y velocidad (velocitas) ${ }^{222}$. La otra, parte de que san Agustín tiene una visión dinámica de la concupiscencia o impulso sexual. Es decir, la mirada no es contemplada más que como una etapa del proceso al que con frecuencia ella misma da curso 223 . La acción mala es, de hecho, sólo el resultado último; las raíces están más profundas ${ }^{224}$. Todo ello unido al peligro de no dar importancia a la mirada por el hecho de que deja a salvo la castidad entendida en su sentido físico ${ }^{225}$. Pero, en la medida en que la concupiscencia de la carne va asociada al placer, puede acabar en una esclavitud que se siente incluso gratificante ${ }^{226}$. La importancia de las miradas no es baladí: convierten al siervo de Dios en esclavo de los sentidos y apartan lejos de Dios el deseo profundo de su corazón 227.

Las reflexiones que acompañan a estos datos son de distinto signo. Agatha Mary encuentra en el capítulo un ejemplo de la teoría de W. Lynch, esto es, que el movimiento ascendente hacia la iluminación y visión sólo es posible si antes ha existido un descenso hacia la dura y mancillante experiencia de la vida 228 . Pero lo habitual y lógico es quedarse dentro del pensamiento agustiniano. Prácticamente todos los autores admiten el fundamento bíblico de la prescripción agustiniana. Como texto base proponen Mt 5,28 ${ }^{229}$, unido a algún otro pasaje ${ }^{230}$. Pero esa base bíblica no les parece suficiente para expli-

219. Marie-Ancilla, 216; V. Grossi, Ascetica del corpo, 319.

220. VAN BAVEL, 60; BOFF, 112.

221. Marie-ANCILla, 219. El punto de partida es bíblico: $1 \mathrm{Jn}$ 2,16 y remite a conf. $10,30,41$.

222. Cf. SAGE, 227; MARIE-ANCILla, 217; A. MANRique - A. SAlas, 160. La referencia es a $s .56,12$.

223. BoFf, 113. Y cita a Hugo de san Victor que señala las siguientes etapas: mirada afecto - fantasía - deleite - consentimiento - acción - hábito - necesidad. A. MANRIQUE - A. SALAS, 164.

224. ZUMKELLER, 78 .

225. MARIE-ANCILLA, 217, que remite a s. 132,3.

226. MARIE-ANCILLA, 219.

227. MARIE-ANCILLA, 219.

228. AGATHA MARY, 155.

229. MARIE-ANCILLA, 216; VAN BAVEL, 60; BOFF, 112.115.

230. Por ej. Mt 6,22: BofF, 115; otros: Lc 11,34; Jb 31,1: cf. SAGE, 227. 
carlo todo. Por ello, traen a colación otros aspectos del pensamiento del santo. Como es muy comprensible, sale a relucir luego, desde perspectivas diferentes, la comprensión agustiniana de la concupiscencia 231. Siempre desde planteamientos específicamente agustinianos, establecen la distinción entre el valor positivo de los sentidos, su capacidad de sensación, y el deseo impuro ${ }^{232}$; dan un notable realce al principio de la interioridad, contrapunto al tema de las miradas ${ }^{233}$. El punto de enganche se lo ofrecen tanto la experiencia ${ }^{234}$, como dos textos bíblicos: 1 Cor 15,33235 y, sobre todo, Mt 5,28. Este último texto posibilita el tránsito de lo exterior a lo interior o, más en concreto, de la violación física de la virginidad a la infidelidad del corazón ${ }^{236}$. El motivo de la interioridad permite otros desarrollos: hay quien pone el acento en que todo ocurre primero en el corazón del hombre, manantial de sus actos 237 ; quien lo pone en señalar que la esencia de la castidad está en el corazón, donde nadie la puede destruir; que, aunque no es suficiente, lo interior es siempre lo principal 238; o, con formulación diferente, que la continencia es una virtud del espíritu, no del cuerpo; que es res animae ${ }^{239}$; que, aunque está en el cuerpo, no es del cuerpo ${ }^{240}$. Tampoco falta quien vincula pensamiento y acción, indicando que «no piensa bien quien no obra bien. No piensa mal quien no obra mal. Toda ejecución sale del césar cordial» 241. Si la Regla es tan severa con la mirada impura se debe a que anuncia ya un corazón enfermo.

En línea con lo anterior, y ya en un plano más teológico, se señala cómo san Agustín insistió siempre con fuerza en la espiritualización de la idea de la virginidad: la virginidad corporal no es más que la forma de una fe virgen, es decir, de una virginidad inquebrantable de la fe ${ }^{242}$. Se contempla la Regla

231. Cilleruelo, 319; Cilleruelo, Comentario, 347; un autor señala cómo la psicología y pasicoanálisis han dado otra valoración distinta de la agustiniana (BOFF, 114).

232. VAN BAVEL, 60-61, que remite a c. Iul. imp. 4,29; s. dom. m. 1,12,33.

233. MARIE-ANCILla, 218, que remite a cont. 1,2 y 2,3.5 en que san Agustín comenta Mt 15,19 .

234. Se hace alusión al peso de la experiencia sobre lo difícil que es quitar el freno a la concupiscencia (MARIE-ANCILLA, 217).

235. A. MANRIQUE - A. SAlAS, 60, quien señala como el Apóstol no hace sino recoger un proverbio de Menandro.

236. VAN BAVEL, 61.

237. van Bavel, 61; A. Manrique - A. Salas, 160; Cilleruelo, 347: «las puertas del castillo interior sólo pueden abrirse desde dentro»; ZUMKELLER, 78.

238. BOFF, 116.

239. BOFF, 84.

240. BOFF, 115. Cita b. con. 21,25; ciu. 1,18; MARIE-ANCIlla, 218.

241. Cilleruelo, 319.

242. T. VAN BAVEl, La espiritualidad de la Regla de san Agustín, en Augustinus 12 (1967) 433-448: 444. 
colocada en el mismo plano de radicalidad que Jesús manifiesta en Mt 5,28, sin admitir medias tintas. Nada ha de salirse del proyecto fundamental de consagración al Señor y a su Reino. Tal es su verdadero espíritu 243 . Y se recuerda que la guarda de la castidad procede en último término de Dios, pero a través del hombre y con su cooperación ${ }^{244}$. Se advierte asimismo que previene contra racionalizaciones y pretextos acomodaticios, apelando incluso a Tit 1,15 245; se la ve, además, como lugar de curación, por otra parte sólo posible si existe compasión 246 .

Las referencias a otras obras de la época son mínimas, pero no falta una a la célebre carta 22 de san Jerónimo en que el monje de Belén señala que la virginidad puede perderse con el pensamiento ${ }^{247}$.

El contenido del parágrafo que nos ocupa no ha recibido una valoración unánime. Según los autores o según los aspectos concretos se valora positiva o negativamente. Comenzamos por las críticas. L. Verheijen se pregunta si la lascivia en la mirada no es tal vez algo abstracto e irreal. Luego reprocha al santo no tomar en cuenta casos particulares en el ámbito de la sexualidad, sobre todo considerando que los admite en el ámbito de los bienes materiales, y se lamenta de que Mt 5,28 no haya invitado a san Agustín a ser más existencial en la Regla. Añade asimismo que la presentación impersonal de dicho pasaje evangélico corre el riesgo de haber causado mucho mal, haber suscitado escrúpulos y haber desanimado a corazones generosos ${ }^{248}$. Al legislador se le reprocha también el modo abrupto de entrar en materia ${ }^{249}$; el excesivo énfasis en la mirada 250 ; una orientación demasiado subjetivista y negativa de la imagen de la mujer, reduciéndola a una cosa manipulable ${ }^{251}$, a una cosa y una cosa peligrosa ${ }^{252}$. Se le recrimina asimismo el clima general en que la castidad es tratada, poco luminoso y exaltante; la falta del ideal evangélico del

243. BOFF, 113-124.

244. A. MANRIQUe - A. Salas, 165, que remite a s. uirg. 51,52; en. Ps. 126,3; 93,30.

245. BOFF, 115.

246. Agatha Mary, 156.

247. Agatha Mary, 156.

248. Le célibat, 59-60 NA 1,123-124.

249. ib. 85-86 NA I,149-150; BOFF, 101.

250. BOFF, 113.

251. BoFF, 122.

252. BoFf, 102. El autor trascribe una carta en que dos jóvenes religiosos exponen las impresiones que les susitó la lectura de este capítulo de la Regla. El texto sigue en estos términos: «La Regla no enseña a relacionarse en forma madura y serena con la mujer, sino a protegerse de ella como una amenaza... la tendencia sexual no es contemplada en ella de forma positiva. Es vista como un declive que lleva hasta el abismo.... la mujer es el acabose». Luego establece la comparación con otras Reglas monásticas, destacando la sobriedad 
celibato por el Reino ${ }^{253}$; un tipo de relación afectiva, típica de una forma de vida religiosa controlada y segregada ${ }^{254}$; una formación que daría como resultado religiosos cerrados en sí mismos, medrosos, que no ven más que peligros en cualquier mujer; el peligro de caer en una visión moralizante y puritana, como si la dinámica del amor representara una perversión 255.

Pero no todo son críticas. Hay quien considera providencial para los que viven en los monasterios que el santo haya hablado abiertamente, porque muy pocas personas están enteramente libres de algun desajuste en la aceptación de su propia naturaleza sexual 256; quien juzga oportunas sus normas para dominar la concupiscencia de la carne 257 ; quien valora como consejo prudente y discreto el señalar que se custodiará la castidad guardando los sentidos ${ }^{258}$; quien pondera la sabiduría de sus prescripciones ${ }^{259}$, o su sólida base bíblica ${ }^{260}$; quien juzga que sus puntos de vista gozan de validez permanente, más allá de la circunstancia que los vio nacer ${ }^{261}$. Incluso quien se muestra más crítico con el texto en cuestión reconoce que la Regla es sabia, pues enseña antes a prevenir que a remediar 262 .

No han faltado tampoco respuestas a algunas de las críticas antes expuestas. Frente a quienes se sorprenden del vigor con que san Agustín condena toda mirada concupiscente, a diferencia de la comprensión que muestra en lo concerniente a la pobreza, Marie-Ancilla advierte que el reproche contra el santo recae en última instancia sobre Jesucristo mismo, y que la razón de su oposición absoluta hay que buscarla en la caridad ${ }^{263}$. De hecho, toda

de estas frente a la amplitud de la agustiniana en cuanto al tema de la castidad ( $i b$.). Sobre este último particular, cf. también AgATHA MARY, 153.

253. BOFF, 101.

254. BoFF, 116.

255. BoFF, 114. Incluso señalando los límites de la visión agustinana de la concupiscencia, superados por la psicología y psicoanálisis, advierte también del peligro contrario: el de negar la fuerza del pecado en este ámbito y el de banalizar el sexo y el amor.

256. Agatha Mary, 155.

257. A. MANRiQUe - A. SAlas, 159

258. Zumkeller, 78; Cilleruelo, 308.

259. SAGE, 227.

260. BOFF, 113.

261. AgATHA MARY, 157-158. La autora pone un ejemplo: «You can listen to and appreciate Handel's Water Music in a concert hall, in a car, in the jungle, anywhere - you do not have to be in a barge or on the embankment of the River Thames to enjoy it, in fact you might find it distracting to your listening if you where by the river. With Augustine and Handel the value of what they wrote trascends its occasion, even though it was formed by that occasion» $(i b$.$) .$

262. BOFF, 113.

263. MARIE-ANCILla, 217. 
mirada concupiscente es reprensible, pues se opone a la determinación fundamental de los siervos de Dios: agradarle sólo a Él 264 .

Los comentaristas no renuncian tampoco a ofrecer orientaciones para el presente. Sin hacer de la Regla una «ley», escribe un autor, es preciso tomarla en serio, pues en la relación hombre-mujer no se pueden permitir juegos irresponsables; hay que ser realistas, no ingenuos adolescentes 265 . Ese mismo autor trata incluso de colocar el capítulo en el contexto del feminismo. En su opinión, si se libera a la Regla de su orientación demasiado subjetivista y negativa de la mujer, puede servir de crítica a la mirada distorsionada sobre ella y de estímulo para mirarla con los ojos del creador 266.

\subsection{Parágrafo quinto}

Para retraer al siervo de Dios de las miradas lascivas, el legislador le advierte que puede ser visto por otro hombre y, en cualquier caso, por Dios. Aunque los comentaristas prestan casi toda su atención al segundo caso, no se olvidan del todo del primero. Al respecto, se pone de relieve la finura de la observación psicológica 267 y se menciona la posibilidad del escándalo ${ }^{268}$. A su vez causa sorpresa el recurso del santo al Altísimo inspector, como justiciero último, pues eso significa que los hombres ya no pueden descubrir la complicidad ni entablar procesos ${ }^{269}$. Se observa cómo el legislador, tras haber evocado ya el ser y presencia de Dios, introduce ahora su actividad. Resulta significativo que lo haga en relación con el pecado del hombre, teniendo $\mathrm{Rm}$ 2,4 en el trasfondo 270 . Amplio espacio merece la ponderación de su sabiduría, apoyada con abundantes textos bíblicos, tanto del Antiguo como del Nuevo Testamento ${ }^{271}$. Esa sabiduría de Dios se manifiesta en su paciencia, a

264. MARIE-ANCILLA, 218.

265. Boff, 116, que remite a Prov 6,27-28.

266. BoFf, 123.

267. BOFF, 117.

268. SAGE, 228.

269. Cilleruelo, Comentario, 370. «En la misma Regla encontramos altibajos. Junto a principios espléndidos y observaciones sutilísimas hay minucias de ordenancista provinciano, suspicaz y receloso, diametralmente opuesto a la imagen que de él arrojan otros textos. Y, como última instancia, por si fallan las otras razones, recurre al Dios Inspector, al Ojo universal y longividente, que todo lo ve y anota para el día de la cuenta» (J. VEGA, Presentación de la obra de L. Cilleruelo, Comentario, 5).

270. AGATHA MARY, 159.

271. Quien más detenidamente lo ha hecho ha sido L. Verheijen. Señala, en concreto, además de Pr 27,20, según los LXX y Mt 5,28, Si 9,5.8; Jb 31,1. La idea del «inspector» evoca Pr 24,12. Que a este Inspector nada puede quedar oculto (latere) remite a Jb 11,11; 23,10; 
la que se asignan como objetivos dar tiempo para la conversión y prevenir a los puros y sanos 272 .

El protagonismo lo obtiene aquí el motivo del temor. Se indica de qué temor se trata, se le asigna una función específica y se valora el recurso a él. Se recuerda la constante distinción agustiniana entre el temor servil y el temor casto; el primero que actúa para evitar el castigo; el segundo, movido por el amor. Con referencia a Dios, la Regla señala dos motivos de temor: el ser visto por él y el desagradarle ${ }^{273}$. En su comentario, los autores reconocen esos grados en el temor de Dios y su función específica ${ }^{274}$. Pero la tendencia es a pensar sobre todo en el temor casto, inseparable del amor y presente en aquel a quien nada duele tanto como desagradar al Señor 275 . Con esta expresión el legislador apenas roza la mística de la castidad consagrada 276. Partiendo de que san Agustín aún no había descubierto la riqueza de los horizontes luminosos del celibato evangélico, la referencia al temor (casto) se interpreta como un leve indicio, un gancho a que agarrarse que permite recuperar algo de la luz que el mismo san Agustín habría de proyectar posteriormente sobre el tema ${ }^{277}$. No falta quien ve las cosas de forma más positiva y encuentra formulado ahí el ideal paulino, no en su perfección como lo hace en la obra La virginidad consagrada, sino en forma negativa, como primera etapa para llegar a él 278 . En la voluntad de agradar al Señor se descubre la

Sal 32,13-14; Sb 1,8; Si 15,18-19;23,19; Mt 6,4; Hb 4,13; que Dios es paciente y da tiempo al pecador para que se convierta, a Sb 1,6; 11,24(23); 12,20; Si 5,6; Ez 33,11; Rm 2,4; 1 P 3,9); el temor del Señor, a Si 15,18-19 (Cf. Le célibat, 54-56 NA I,118-120; también MARIE-ANCILLA, 221; VAN BAVEL, 61).

272. A. MANRIQUe - A. SAlas, 166, que remite a Gn. Litt 11,8,10-11; ciu. 1,8; pat.1,1; MARIE-ANCILLA, 221; VAN BAVEL, 61: «La rapidez de los hombres para condenar es muestra frecuente de poca sabiduría. Una condenación precipitada hunde más al faltón, le quita toda esperanza y disminuye la posibilidad de que se corrija. Cuando más sabio es uno, más conoce su propia pequeñez, y más paciente es». Sobre la paciencia de Dios, cf. SR. DoucELINE, A l'image de "Celui dont la Sagesse sait temporiser en vue du Bien", en Augustiniana 41 [1991] 805-813: 808-813.

273. MARIE-ANCILLA, 221.

274. Cilleruelo, 327.335; Comentario, 362-363; Marie-Ancilla, 221.

275. TRAPÈ, 150; BOFF, 118 (que remite a s. uirg. 38,39; 39,40 y a Ex 34,14 en que Dios se presenta como un Dios celoso); ZuMKeller, 79-80; Cilleruelo, 362; MARIE-ANCILlA, 221; SAGE, 229: «Para un alma virginal, no puede tratarse de temor servil sino del amor casto", y remite a en. Ps. 127,8-9, s. uirg. 39, y Sir 23,4-6. Otros prefieren hablar más bien de temor reverencial (A. MANRIQUE - A. SALAS, 165).

276. BOFF, 119.

277. BofF, 119, Presenta s. 161,11,12 y s. uirg. 22,$22 ; 27,27$ como referencias que permiten percibir la atmósfera religiosa y sublime que baña el voto de castidad, cuya mística es profundamnete cristocéntrica y en extremo positiva (ib. 119-120).

278. MARIE-ANCILLA, 221. 
motivación de la castidad del corazón ${ }^{279}$. En este contexto se trae a colación la belleza espiritual mencionada en el último capítulo ${ }^{280}$. La recomendación que el legislador hace al siervo de Dios de que piense que Dios le ve se considera como obvia desde ese presupuesto del temor casto o amor. El amor es de por sí absorbente; en cuanto se instala en el corazón, no deja pensar en otra cosa. Recíprocamente se reclaman el amor y el trato. El amor se alimenta de pensamientos y de la presencia del amado 281 . Sin olvidar que el pensamiento de que los ojos de Dios reposan en el alma no es sólo «deleite de amor, sino procedimiento ascético» 282 .

Siendo evidente el valor del temor casto, los autores asignan también una función al temor servil. El temor al qué dirán puede ser malo o bueno y apreciable 283 . Hay que reconocerle su rol en la vida cristiana, aunque corra el riesgo de aparecer como poco evangélico ${ }^{284}$. Se le asigna una función pedagógica $285 \mathrm{y}$, partiendo de que la idea de Dios Padre es inseparable de la de Dios juez, se ve en el un medio profiláctico ${ }^{286}$. Siempre está presente el peligro de interpretar mal la paciencia de Dios ${ }^{287}$. Se pone el acento en la motivación: aunque parezca que trata de intimidar y disuadir, la motivación es religiosa: es la espiritualidad de la presencia de Dios 288 . Aun reconociendo la mala prensa del altísimo Inspector, porque el hombre se ha creado una picaresca sofisticada para no ver o anublar la mirada divina, se juzga que no hay ejercicio mejor 289 .

279. MARIE-ANCILLA, 221.

280. ZUMKELLER, 80.

281. CILlERUELO, 323. « ¿Quién recomienda a un enamorado que piense en el objeto de su amor? Pero si tenemos que esforzarnos para pensar en Dios, sin duda es claro que (no) le amamos al menos con cierta intensidad» (Cilleruelo, Comentario, 362).

282. Cilleruelo, 333. «Y he aquí que la presencia de Dios nos llama al orden sin cesar. Los ojos del Señor nos paralizan cuando tratamos de saltar la barrera o sacudir el yugo. Los ojos del Señor nos preguntan en cuanto empezamos a vacilar y a entrar en componendas con las pasiones: Entonces, ¿ya renuncias a Mí? ¿Entonces ya me rechazas? - Tu quoque, fili mi?» (ib.).

283. Cilleruelo, 322.

284. MARIE-ANCILLA, 220.

285. MARIE-ANCILla, 221; A. MANRIQUe - A. SALAS, 165.

286. A. MANRIQUE - A. SALAS, 165-166. CiLleRUelo, 355: «El veredicto social es para el religioso una barrera, como una conciencia externa y colectiva; en la mirada ajena descubrimos un juez, aunque se reserve el juicio. Se le puede considerar como un policía o colonizador insoportable, pero también como un ángel de la guarda que calla y ayuda».

287. MARIE-ANCILlA, 222; A. MANRIQue - A. SALAS, 166. El que peca no ha de sentirse seguro porque no actúe de inmediato Dios paciente y de mucha misericordia: Ex 34,6; Num 14,18; Sal 86,15; Joel 2,13... Rom 9,22 (ib.).

288. Cilleruelo, Comentario, 355-356. 362; Boff, 117; Sage, 229.

289. Cilleruelo, Comentario, 356. 
Con esto hemos entrado ya en la valoración del contenido del parágrafo. Se habla de método represivo y expresiones rudimentarias, explicables por el bajo nivel cultural y moral de los siervos de Dios 290 ; de represora se tacha también la tradición espiritual de la presencia de Dios porque lo presenta como un policía; de espiritualidad no muy elevada, apta sólo para espíritus mal formados que actúan únicamente por miedo al castigo, aunque se reconoce que la Regla la redime poniéndola en un plano más elevado 291 . Asimismo en el pensamiento de san Agustín -se afirma- se siente constantemente el peligro de pasar insensiblemente de Dios como «máximo» a Dios como «único» y así crear oposiciones artificiales y rígidas entre el creador y la criatura, entre Dios y la mujer 292.

En cuanto a la cita bíblica usada por el santo (Prov 27,20 LXX) se observa que va precedida en el texto sagrado por estas palabras: «los ojos de los hombres son insaciables» 293 .

\subsection{Parágrafo sexto}

Es el último parágrafo de la primera parte del capítulo. Se ve en él un ejemplo más de un aspecto fundamental de la Regla, el de las relaciones mutuas dentro de la comunidad. Al respecto, no se percibe tanto la responsabilidad individual de cada siervo de Dios, como la del grupo en su totalidad cuando el siervo de Dios se halle en lugares donde haya mujeres ${ }^{294}$. También a este respecto se advierte que la Regla, en cuanto escrito concreto, huye de todo misticismo abstracto 295 .

El punto de partida, con apoyo en el texto monástico, es que la salvaguarda de la castidad es siempre obra de Dios ${ }^{296}$. Pero con eso no está dicho todo, pues Dios actúa de diversas maneras, según sus modos de presencia: desde su propio ser que conoce, entiende y cuida, y desde el hecho de su pre-

290. De VoGÜE, 3,190-191.

291. BOFF, 117-118.

292. BOFF, 118-119.

293. Agatha MaRY, 160. Y añade: «The tragedy of this insatiable monk in that his thirst for God is in danger of accepting a substitute» $(i b$.).

294. vAN BAVEL, 62; AGATHA MARY, 162. El remitir en este contexto al dato de san Posidio de que ninguna mujer entró en casa de Agustín (Vita Augustini, 26; cf. A. MANRIQUE - A. SALAS, 165; MARIE-ANCILLA, 134) nos parece fuera de lugar porque el texto trata más bien de una actitud contraria.

295. BOFF, 122.

296. SAGE, 230; BoFF, 122, que remite a conf. 10,29,40. 
sencia dentro y en medio de los hombres (Mt 18,20) 297 . Es este segundo aspecto el contemplado en el parágrafo: Dios otorga su protección a través de los hermanos 298.

El punto más importante se descubre en el ex vobis. Quien pone su atención en la preposición ex, ve evocada la interioridad de la actividad de Dios, que vive y actúa dentro de cada uno ${ }^{299}$. Quienes, por el contrario, se fijan más en el vobis, en ese plural ven indicada la presencia de Dios en la comunidad. El significado del texto sería: Dios nos guarda por medio de la comunidad, de las personas que nos rodean, o Dios nos guardará por nuestra responsabilidad mutua. La comunidad, pues, es responsable en el bien y en el mal de los otros ${ }^{300}$. No falta quien une las dos presencias divinas, al afirmar que el Dios de san Agustín no planea en el aire, sino que está dentro de la comunidad, en lo íntimo de cada hermano ${ }^{301}$.

Este precepto lo fundamenta explícitamente el legislador en el hecho de la inhabitación divina ${ }^{302}$, puesta en relación con el parágrafo último del primer capítulo, pues en ambos textos los siervos de Dios son presentados como templos de Dios ${ }^{303}$. Sólo que aquí el tema no aparece vinculado a la idea de la unidad, sino al peligro de la profanación y la necesidad de tenerlo limpio, con referencia a 1 Cor 3,16-17 304. Al mismo precepto subyacen otros dos convencimientos: uno, que la fraternidad es el ámbito espiritual donde la castidad

\section{Agatha MaRy, 165}

298. MARIE-ANCILlA, 134. Esta autora introduce el comentario de este parágrafo, de forma caprichosa, nos parece, dentro de un capítulo titulado: «La unidad fundamento de un modo de vida» y bajo el epígrafe: «Velar por la observancia de los preceptos, un deber para todos». TRAPÈ, 153, que remite a conf. 10,29,40.

299. AgATHA MARY, 165-166, quien advierte que el texto no dice $a b$ vobis, sino $e x$ vobis. Es decir, no se trata de librar «de vosotros» - a menudo los hombres son sus peores enemigos y necesitan ser protegidos de ellos mismos-, sino de librar «a partir de vosotros» (ib.).

300. vAN BAVEL, 62; ID., The evangelical Inspiration of the Rule of St. Augustine, en The Downside Review 93 (1975) 83-99: 96; TrAPÈ, 153. No nos parece exacto hablar de que la Regla insiste en el aspecto comunitario de la virginidad (T. VAN BAVEL, La espiritualidad de la Regla de san Agustín, en Augustinus 12 [1967] 433-448:445 y The evangelical inspiration, 96); nos parece más exacto referirse específicamente a la guarda de la virginidad.

301. BOFF, 122, que remite también a praec. 1,8 .

302. A. Manrique - A. Salas, 167; Agatha Maky, 165; Marie-Ancilla, 133, que remite a Ef. 3,17 y s. uirg. 51,52.

303. Agatha MaRY, 165

304. AgAtha MARY, 165: «And this is the force of what Augustine is saying...: You could, if you gave way to your weakness, desecrate the dwelling-place of God which you yourself are. But... if you remain attentive to him who is within you then he himself can protect you from the efect of the downward drag of your nature». De esta inhabitación se deriva la necesidad de cumplir lo prometido: la libertad en el voto hace mayor la obligación (A. MANRIQUE - A. SALAS, 167-168, remitiendo a ep. 127,7; s. 148,2,2; b. uid.11,14). 
encuentra su mejor garantía de defensa y desarrollo, como afirmó el mismo Vaticano II ${ }^{305}$ y, mucho antes, el concilio de Hipona del 393 en el que participó san Agustín 306 ; otro, que tampoco a nivel de fe se puede olvidar el carácter social del hombre 307.

De este contexto doctrinal surge el concepto de la responsabilidad mutua ${ }^{308}$. De acuerdo con él, se señala que, en el contexto específico de que trata el capítulo y el parágrafo, los siervos de Dios han de ver a los demás como instrumentos de Dios, presencia visible suya, agentes ministeriales de su divina y oculta actividad, instrumentos y servidores, «encarnación» de la protección que Dios da a cada uno ${ }^{309}$. La presencia del otro con quien se comparte buena parte de la vida se valora como un medio y un lugar de seguridad 310; nunca se entiende al otro como un inquisidor, sino como un sostenedor; su presencia, impulsada por la solicitud ${ }^{311}$, no se la juzga como de control policial, sino como ayuda ${ }^{312}$. La razón para asumir la responsabilidad por el otro se fundamenta en el cuidado de Dios por cada uno ${ }^{313}$.

También se mencionan formas concretas de ejercer la ayuda: advertir al siervo de Dios, recordarle lo que Dios espera de él ${ }^{314}$, o el respeto mutuo, la amistad, la corrección fraterna y la humildad ${ }^{315 .}$

\section{Valoración}

Hacer una valoración detallada de cuanto hemos presentado, síntesis de las aportaciones de otros comentaristas de la Regla, implicaría multiplicar demasiado las páginas. Por ello, nuestras reflexiones dejarán de lado los puntos concretos de uno u otro autor y se centrarán en los aspectos de carácter

305. Perfectae caritatis, 12b. Cf. Boff, 121; Trapè, 153.

306. VAN BAVEL, 62; BofF, 121; MARIE-ANCILla, 134, n. 1.

307. VAN BAVEL, 63, que añade: «verdad que merece reflexión continuada».

308. MARIE-ANCILla, 133; Boff, 121 que remite a Caín y Abel (Gen 4,9). cf. también sobre Caín Agatha MARY, 162.

309. Marie-Ancilla, 133-134; Cilleruelo, Comentario, 338; Agatha Mary, 162.

310. Agatha Mary, 166.

311. Agatha MaRY, 162, que remite a NA I,112-113.

312. Agatha Mary, 162.165; Boff, 121.

313. Agatha MaRY, 162.

314. MARIE-ANCILla, 134. Es dedir, que interpreta el resto del capítulo desde este parágrafo.

315. TRAPÈ, 153. Los tres primeros los encuentra en la Regla y el último en s. uirg. 51,52. Pero en este caso no se trata de ayuda que pueda venir de los demás. A la humildad remite también MARIE-ANCILLA, 214; ZUMKELLER, 79; BOFF, 121. 
general que conciernen a un grupo de ellos, cuando no a la mayoría. La valoración de los otros puntos resultará, por vía indirecta, del comentario que ofreceremos en la segunda parte.

Nuestra primera observación constata la falta de visión orgánica del capítulo. Esto se entiende en dos sentidos, uno más exterior, otro más interior. En el primero, falta esa visión orgánica porque, en general, se establece una separación innecesaria entre los tres primeros parágrafos y los siguientes, asignándoles argumento distinto; en el segundo porque, aunque consideren que el tema único del capítulo es el de la castidad, independientemente del nivel en que se considere, no presentan una línea de pensamiento que integre todos y cada uno de los parágrafos con orden lógico. Se contemplan distintos aspectos relacionados con la virtud, pero sin mostrar una neta ilación entre ellos. Ahora bien, san Agustín es un hombre que conoce de maravilla, en la teoría y en la práctica, las reglas de la composición y, en principio, no cabe admitir que le falte un hilo conductor.

Hemos visto cómo varios comentaristas, siguiendo sobre todo a L. Verheijen, muestran su extrañeza por la terminología y el contenido conceptual del capítulo. En concreto, echan de menos una terminología más técnica como «castidad perfecta», «virginidad consagrada», «celibato por el Reino» $u$ otras formas similares, y, más allá de las carencias terminológicas, echan de menos el ideal de la virginidad/celibato consagrados y el voto mismo de castidad, lamentando que se haya quedado en sus simples límites ascéticos. Al respecto diremos que no cabe pedir de un texto lo que su autor no quiso darle. El error proviene, en parte, de leer la Regla con criterios que no le cuadran.

Ya indicamos cómo, a nuestro parecer, en el capítulo cuarto el legislador se limita conscientemente a los aspectos ascéticos del voto de castidad o a la virtud de la castidad en el nivel requerido a los siervos de Dios. Por tanto, en vez de lamentar que el legislador se haya quedado sólo en el nivel ascético, una vez reconocido que es así, lo que procede es asumirlo con todas las consecuencias y dar razón de ese proceder. Es lo que ha hecho L. Verheijen.

El agustino holandés trató de explicar las lagunas que él percibía en la Regla no desde la intención del legislador, sino desde sus carencias. Según él, en el momento de la evolución doctrinal en que se encontraba cuando la compuso, el santo no podía dar lo que aún no tenía. Si aún no había llegado a una teología del matrimonio, mucho menos podía haber alcanzado una teología del celibato o virginidad consagrados ${ }^{316}$. El celibato era para él un dato

316. «Il est en effet impossible, me semble-t-il, d'avoir des idées très poussées sur le célibat consacré tant qu'on a des idées peu avancées sur son antithèse, le mariage chrétien» (Le célibat, 85 NA I,149). Cf. AGATHA Mary, 194. 
tradicional, al que aún no había encontrado motivación específica ${ }^{317}$. Aunque algunos autores, según vimos, le hayan seguido en este razonamiento, sus argumentos distan mucho de ser convincentes. Ya Marie-Ancille ha rechazado, creemos que con razón, que para san Agustín el celibato fuera sólo un dato de hecho y que careciera de toda teología al respecto. Y se apoya en dos argumentos: uno, la experiencia traumática de su conversión que, en cuanto significó la opción por el celibato, no pudo tener lugar sin unas motivaciones religiosas o teológicas; otro, el que la obra La virginidad consagrada puede que no sea posterior a la Regla sino contemporánea 318.

Aparte estos datos, tampoco nos parecen acertadas las conclusiones de los análisis de los textos hechos por L. Verheijen. Hagamos un breve repaso de los mismos.

El primero está tomado del apóstrofe que dirige a la Iglesia en la obra De moribus ecclesiae. El santo escribe:

Con razón es tuya esa multitud de personas hospitalarias, serviciales, misericordiosas, sabias, castas y santas, muchas hasta tal punto ardiendo en el amor de Dios que, en su continencia absoluta y su increíble desprecio del mundo, llegan hasta encontrar sus delicias en la soledad 319.

El subrayado corresponde al de L. Verheijen. Pero se puede advertir que ha subrayado dos manifestaciones ascéticas paralelas y no la motivación de

317. «Somme toute, la lecture des oeuvres de saint Augustin qui ont été entreprises entre 386, date de sa conversion, et le début de son épiscopat, nous a fait comprendre qu'il ne s'était pas ancore livré à des réflexions très personnelles sur le sens profond du célibat monastique. Le célibat constituait alors pour lui sur tout une donnée traditionnelle: un moine ne se mariait pas» (le célibat, 85 NA I,149).

318. MARIE-ANCILLA, 215-216. La autora considera que una reflexión sobre los parágrafos 4-6 del capítulo cuarto debe tener como trasfondo la teología de la obra s. uirg. si se la quiere entender en toda su dimensión espiritual. La autora trabaja con la fecha de la obra s. uirg. propuesta por M.-Fr. Berrouard. Según este autor hay que adelantar su fecha de composición varios años, hasta hacerla coincidir prácticamente con la fecha de la Regla (cf. Augustinus Lexikon, 1,659). En la misma línea se coloca G. Lettieri quien sostiene que la primera parte de la obra $(2,2-35,35)$ es anterior a las Confesiones y el resto, junto con la introducción, ya posterior (L'altro Agostino. Ermeneutica e retorica della grazia dalla crisi alla metaformosi del De doctrina christiana, Brescia 2001, pp.218-221). Por su parte, P. M. Hombert considera también que la obra fue compuesta en dos momentos, pero coloca la primera parte, a finales del 403 o comienzos del 404, y la segunda (a partir de 38,39) hacia el 412, una vez surgida ya la polémica antipelagiana (PIERRE-MARIE HOMBERT, Nouvelles recherches de chronologie augustinienne, Paris 2000, p. 109-136).

319. «Merito tibi tam multi hospitales, multi officiosi, multi misericordes, multi docti, multi casti, multi sancti, multi usque adeo dei amore flagrantes, ut eos in summa continentia atque mundi huius incredibili contemptu etiam solitudo delectet» (mor. 1,30,64). Cf. Le célibat, 62 NA I,126. 
una y otra, que es lo que precede a ambas: el ardiente amor de Dios 320 . Él interpreta que todos los adjetivos se refieren a los mismos, a los anacoretas, algo difícil de sostener. El texto designa distintas categorías de personas merecedoras de admiración en el interior de la Iglesia, y entre ellos hay que contar a algunos en los que el amor a Dios llega a tales niveles que hasta hallan sus delicias en la soledad. Los anacoretas constituyen una categoría entre otras, aunque colocados en la cima del escalafón ${ }^{321}$. Por eso, no nos parece correcta la conclusión de L. Verheijen:

Cuando el lector se pregunta cuál es la razón del ser del celibato y la razón de su excelencia, no halla en este texto respuesta alguna, salvo tal vez el desprecio del mundo que se manifestaría en él ${ }^{322}$.

Salta a la vista que ha tomado como motivación de una práctica ascética, el celibato, la otra práctica ascética, el abandono del mundo, y no ha tomado en consideración lo que da razón de una y otra: el ardiente amor de Dios. Un amor que es superior al que poseen las demás categorías de personas virtuosas mencionadas ${ }^{323}$.

Un segundo texto está tomado del capítulo siguiente de la misma obra:

¿Qué ven, pregunto, estas personas, que no pueden no amar a los hombres y son capaces, sin embargo, de pasar sin verles? Sea lo que fuere, ciertamente es algo más excelente que las cosas humanas, si, entregada a su contemplación, una persona puede vivir sin la compañía de otra persona. Aprended pues, maniqueos, a conocer esta forma de vida y la continencia extraordinaria de estos cristianos perfectos para quienes la castidad plena aparece no sólo como digna de ser alabada, sino también merecedora de ser abrazada... ¿Quién no sabe... que una muchedumbre de cristianos de una continencia absoluta se extiende por toda la tierra, cada día más, sobre todo en Oriente y en Egipto? ${ }^{324}$.

320. Por cierto que Agustín utiliza un término latino, flagrantes, presente también en la Regla (cf. praec. 8,1, 1. 238).

321. Entre otras cosas, mal se entienden referidas a los anacoretas las primeras virtudes mencionadas: hospitalidad, servicialidad, misericordia... Sólo hace falta leer la descripción que hace de ellos algo más adelante en mor. 1,35,65 (cf. la nota 324), donde afirma que los anacoretas «son incapaces de no amar al hombre y, sin embargo, son capaces de pasar sin verle». De monjes así, esto es, capaces de pasar sin ver a otros hombres, aunque los amen, ¿cómo puede ponderase su hospitalidad y servicialidad?

322. Le célibat, 62 NA I,126.

323. Así se deduce del usque adeo.

324. ««Quid est, quaeso, quod uident qui non possunt hominem non diligere, et tamen possunt hominem non uidere? Profecto illud, quidquid est, praestantius est rebus humanis, 
L. Verheijen comenta con razón que el celibato se halla evocado aquí en un contexto de contemplación y de perfección cristiana. Y añade que la razón de ser de esta opción tan señalada queda en la misma imprecisión que en el texto anterior ${ }^{325}$. Pero ¿no cabe aceptar como motivación de una vida célibe el poder entregarse plenamente a la «contemplación» de ese algo, sin duda Dios, más excelente que todos los bienes de que pueden gozar los hombres (praestantius rebus humanis)? ¿No se puede sobreentender aquí una velada alusión al paulino ocuparse sólo de las cosas del Señor (1 Cor 7,32)? ${ }^{326}$.

El resultado del análisis de los textos mencionados y de algunos otros 327 lo recoge L. Verheijen en estos términos:

Hasta el presente nada nos ha indicado que él haya profundizado en la cuestión de por qué esta opción (el celibato) constituía un ideal tan perfecto. Se contentaba de admirar el «increíble desprecio de este mundo» que se manifestaba en el celibato monástico ${ }^{328}$.

De acuerdo en lo primero, pero añadiendo que en dichos textos san Agustín está exponiendo la vida de los monjes, y no un tratado sobre el celibato o virginidad y que, por tanto, no cabía esperar demasiado. Respecto a lo segundo, estamos en desacuerdo por lo indicado en su momento, al comentar el texto: en él el celibato es una práctica ascética y el desprecio del mundo otra, y no hay por qué asociarlos hasta el punto de hacer de las dos una sola.

Otra de las obras examinadas es La verdadera religión. En sus capítulos iniciales habla de forma muy genérica de los monjes. Señala que renuncian al matrimonio, a las riquezas y a los honores ${ }^{329}$. Tras un breve comentario, L. Verheijen concluye:

cuius contemplatione potest homo sine homine uiuere. Iam enim accipite, Manichaei, perfectorum Christianorum, quibus summa castitas, non laudanda tantum, sed etiam capessenda uisa est, mores et continentiam singularem; ne uos impudenter iactare apud animos imperitorum, quasi difficillima rerum abstinentia, si quid in uobis pudoris est, audeatis. Nec eam dicam quae uos ignoratis, sed quae nobis occultatis. Quis enim nescit summae continentiae hominum christianorum multitudinem quae per totum orbem in dies magis magisque diffundi, et in Oriente maxime atque Aegipto...» (mor. 1,31,65).

325. Le célibat, 63 NA I,127.

326. Por otra parte, no se olvide el elemento contemplativo presente en s. uirg. 54,55.

327. En concreto, mor. 1,31,67.68.

328. Le célibat, 64 NA I,128.

329. «... nunc ... tan innumerabiles aggrediuntur hanc uiam, ut desertis diuitiis et honoribus huius mundi ex omni hominum genere uni deo summo totam uitam dare uolentium desertae quondam insulae ac multarum terrarum solitudo compleatur» (uera rel.3,5). 
Estamos siempre en el mismo punto: el celibato consagrado, netamente considerado como un punto de primera importancia en la vida de los monjes, sin duda su elemento más característico, es evocado con algunas palabras, muy breves, sin que Agustín nos diga explícitamente por qué otorga tal valor a esta opción. El contexto sugiere que es el desprecio del mundo lo que motiva tan alto aprecio del celibato 330 .

Ante estas palabras, en primer lugar, hay que repetir lo dicho anteriormente: no cabe esperar de un texto ocasional y sumamente genérico lo que difícilmente puede dar. En segundo lugar, el pasaje concluye señalando la motivación de la vida de tantos millares de jóvenes de uno y otro sexo que desprecian el matrimonio y viven castamente:

Si es tan elevado el número de quienes emprenden esta forma de vida, que islas en otro tiempo desiertas y la soledad de muchas tierras se encuentran llenas de hombres de toda clase que, dejando las riquezas y honores de este mundo, quieren dedicar toda su vida al único y soberano Dios... 331.

En lo subrayado, que evoca probablemente 1 Cor 7,32, está el motivo de esa forma de vida que incluye no sólo el abandono de las riquezas y honores, sino también el no al matrimonio, y la vida en castidad.

Una motivación del celibato la expone el santo en sus Soliloquios. En aquellos primeros meses de su vida de convertido, lo valoraba como medio al servicio de la búsqueda de la Sabiduría ${ }^{332}$. Perspectiva intelectualista que apenas se nota ya en la obra sobre Las costumbres de la Iglesia ${ }^{333}$.

Se puede estar de acuerdo con L. Verheijen cuando cree poder constatar, como conclusión, que a excepción del pasaje de los Soliloquios, san Agustín no se extiende sobre el lado positivo de su opción ${ }^{334}$. Pero que no se extienda no implica que no lo mencione. Más exacta nos parece, por tanto, la conclusión contraria: cuando, hacia el 397, san Agustín se pone a componer la Regla, contaba ya con motivaciones cristianas para el celibato monástico. Lo entiende como fruto de un flagrare amore Dei, del deseo de entregarse a la contemplación de Dios, de dedicar toda la vida al único y supremo Dios.

En conclusión, si san Agustín no introduce una teología o, por mantener la terminología, una mística de la virginidad o del celibato consagrados hay

330. Le célibat, 67 NA I,131.

331. Vera rel. 3,5. Cf. el texto en nota 329.

332. Cf. Sol. 1,10,17-11,19;1,13,22.

333. Le célibat, 74 NA I,138.

334. Ib. 
que achacarlo no tanto a las carencias del legislador cuanto a su propia voluntad. Una voluntad que se expresa de algún modo mediante la estructura de la Regla. En el capítulo cuarto se ocupa del aspecto moral-ascético; el aspecto místico tiene su propio lugar en el capítulo octavo.

P. DE LUIS

Estudio teológico Agustiniano

Valladolid 